\title{
Whole-rock and mineral chemistry characterization of contrasting granitoids, constraints on the source of the Vieirópolis NYF-type pegmatites, Northeastern Brazil
}

\author{
Igor Manoel Belo de Albuquerque e Souza ${ }^{1 *}$ (D), Ignez de Pinho Guimarães' (D), \\ Sandra de Brito Barreto' (D), Glenda Lira Santos ${ }^{1}$ D, José Ferreira de Araújo Neto ${ }^{1}$ (D)
}

\begin{abstract}
The Vieirópolis pegmatite field is characterized by amazonite pegmatites inserted in the Borborema Province. The Serra Branca pegmatite is hosted by the Serra Branca granites, which intruded partially the Serra Negra granites, and stands out by its amazonite mineralization. To comprehend the crystallization conditions and the source of this pegmatite and associated Serra Branca and Serra Negra granites, petrographic, mineral chemistry, geochronological and whole-rock geochemical data were used. The Serra Branca pegmatite is Cs-, $\mathrm{Rb}$-, $\mathrm{Pb}-$, $\mathrm{Nb}$-, and Ta-rich. The Serra Branca granites $\left(563 \pm 2 \mathrm{Ma}\right.$ ) are metaluminous to weakly peraluminous, crystallized under high $\mathrm{fO}_{2}$ conditions, pressure of 2.68-2.80 kbar and temperatures ranging from $667-670^{\circ} \mathrm{C}$, with many zircon grains showing inherited cores of Paleoproterozoic ages. The Serra Negra granites $(594 \pm 4 \mathrm{Ma})$ comprises metaluminous granites crystallized under high $\mathrm{fO}_{2}$ conditions, temperatures within $711-751^{\circ} \mathrm{C}$, pressure varying from 4.72 to $5.42 \mathrm{kbar}$. Both granites resulted from distinct partial melting degrees of a source similar to the Caicó Complex orthogneisses. The Serra Branca pegmatite geochemical data suggests that it was originated by extreme fractionation of the Serra Branca granites magma. The Serra Branca amazonite pegmatite is the first pegmatite mineralogically and geochemically characterized as Nb-Y-F (NYF)-type from the gadolinite subtype in the Borborema Province.
\end{abstract}

KEYWORDS: Serra Branca amazonite pegmatite; NYF-type pegmatite; mineral chemistry; crystallization conditions; whole-rock geochemistry.

\section{INTRODUCTION}

The Borborema Province (BP) in Northeastern Brazil hosts one of the largest, in global scale, pegmatite Province - the Seridó Pegmatite Province (SPP; Santos et al. 2014), located in the Rio Grande do Norte domain of the Northern sub-province. The pegmatites from the SPP are known since the First World War when the mica exploitation started. By the end of the Second World War, the SPP became globally famous due to the production of Ta ore and the beautiful species of exotic minerals (Beurlen et al. 2009). According to Černý (1991a, 1991b) and Černý and Ercit (2005), the SPP pegmatites are classified as belonging to the $\mathrm{Li}-\mathrm{Ce}-\mathrm{Ta}$ (LCT) Family rare elements class, within the beryl-columbite, beryl-columbite-phosphate and spodumene sub-types (Da Silva et al. 1995, Beurlen et al. 2008). Besides the SPP, the Northern sub-province hosts the Solonópoles-Quixeramobim pegmatite district in the Ceará domain (Souza 1985). The pegmatites in the SolonópolesQuixeramobim district are dominantly LCT-type, and the

\footnotetext{
${ }^{1}$ Universidade Federal de Pernambuco - Recife (PE), Brazil. E-mails: igor.manoel.belo@gmail.com, ignez@ufpe.br, sandradebritobarreto@gmail.com, glendaliraa@gmail.com, araujoneto.geo@gmail.com

${ }^{*}$ Corresponding author.
}

presence of gemstones, industrials minerals and others of economic values (beryl, cassiterite, amblygonite, tantalite, columbite, lepidolite and spodumene) has been reported (Vidal \& Nogueira Neto 2005). Many others isolated occurrences of pegmatite are described in the Northern sub-province of the BP (Santos et al. 2014).

The Vieirópolis pegmatite field was reported for the first time by Barreto et al. (2016), and it constitutes the first reported occurrence of a pegmatite field out of the SPP, in the Rio Grande do Norte domain. The Vieirópolis pegmatite field is characterized by amazonite- and/or beryl-bearing pegmatites. The presence of amazonite classifies these pegmatites as Nb-Y-F (NYF)-type (Martin et al. 2008), thus, being the first NYF-type pegmatite identified in the BP.

This paper focuses on the study of two plutons (Serra Branca and Serra Negra) and the Serra Branca amazonite pegmatite of the Vieirópolis field. We present petrographic, U-Pb geochronological data, mineral and whole-rock chemical data to constraint the conditions of magmatic crystallization and the sources of both granites and the pegmatite.

\section{REGIONAL GEOLOGY}

The BP (Almeida et al. 1981) comprehends an area of $\sim 450,000 \mathrm{~km}^{2}$, in Northeastern Brazil, and it is limited to the south by the São Francisco Craton, to the west by the Parnaíba Basin, and to the north and east by coastal basins. The BP 
comprises Paleoproterozoic gneiss-migmatitic complexes, small Archean nuclei and Neoproterozoic to Mesoproterozoic supracrustal sequences (Van Schmus et al. 1995, 2008, Neves et al. 2008, Guimarães et al. 2016, Silva Filho et al. 2016). According to Van Schmus et al. (2008), the province resulted from the breakup of a Paleoproterozoic supercontinent, Atlantica (Rogers 1996), during the late Mesoproterozoic to early Neoproterozoic. This event was associated with volcanism (mostly felsic) and granitic intrusions, deposition of extensional basins floored by Paleoproterozoic crust approaching small oceans, and a larger ocean between the northern edge of Congo-São Francisco and the West African-Sao Luis cratons.

The actual framework of the BP resulted from the Brasiliano (Pan-African) Orogeny (650-550 Ma; Van Schmus et al.2008), which was responsible for extensive granitic magmatism along with large scale transcurrent shear zones, where the granites are commonly used to date the Brasiliano deformations. Such transcurrent shear zones formed contemporaneous conjugate sets of sinistral NE-SW striking and dextral E-W striking mylonitic belts developed under middle- to high temperature amphibolite facies conditions (Vauchez \& Egydio-Silva 1992, Guimarães \& Da Silva Filho 1998, Ferreira et al. 1998, Neves \& Mariano 1999, Neves et al. 2000, Silva \& Mariano 2000, Neves et al. 2006).

Van Schmus et al. (1995), using the E-W trending Pernambuco and Patos shear zones with dextral kinematic, divided the BP into three major domains, later renamed to sub-provinces (Van Schmus et al. 2011; Fig. 1A): Northern, Transversal and Southern. Each sub-province was divided into domains. The Northern sub-province is subdivided into Rio Grande do Norte, Ceará and Médio Coreaú domains. The studied area is located within the Rio Grande do Norte domain.

The Rio Grande do Norte domain (RGND) is a Rhyacian to Orosirian crustal block bordered in the south by the Patos shear zone and at the west by the Ceará domain (Van Schmus et al. 2011). Besides the Paleoproterozoic rocks, which comprise the Serrinha Pedro Velho and Caicó complexes, it also encloses an Archean nucleus (São José do Campestre) and the NE-trending metasedimentary Seridó Fold Belt. In the RGND, the granitic magmatism is associated to large scale shear zones (Jardim de Sá 1994, Van Schmus et al. 1995, Dantas 1997, Brito Neves et al. 2000, Jardim de Sá et al. 1981) and have crystallization ages ranging from 575 to $540 \mathrm{Ma}$ (McMurry et al. 1987, Leterrier et al. 1994, Jardim de Sá 1994, Trindade et al. 1999, Hollanda et al. 2003, Guimarães et al. 2009, Nascimento et al. 2015). Ages younger than $540 \mathrm{Ma}(\mathrm{Rb}-\mathrm{Sr}$ method) have been recorded by Nascimento et al. (2000), in alkaline intrusions within the Paleoproterozoic Serrinha-Pedro Velho Complex, which is part of the São José do Campestre domain.

\section{GEOLOGICAL FRAMEWORK AND PETROGRAPHY OF THE VIEIRÓPOLIS AREA}

The studied area comprises a Paleoproterozoic basement (Caicó Complex and Poço da Cruz Suite), granitic intrusions (Serra Negra and Serra Branca granitoids) and pegmatite dykes (Fig. 2). The regional NE-SW trend seen in the basement and granitic bodies is associated with the Vieirópolis and Lastro dextral transcurrent shear zones (Araújo Neto et al. 2018). A brittle regime is also characterized by fractures and/or faults predominantly in a NW-SE, and E-W direction is subordinated, cross-cutting the main structures. In regions near to the shear zones, this fracturing pattern is transversal to the mylonitic foliation.

The Caicó Complex (2.25-2.15 Ga) is the high-grade basement of the metasedimentary Seridó Group. It is composed of an older metavolcanosedimentary unit, and a younger and most common metaplutonic unit consisting locally of migmatized

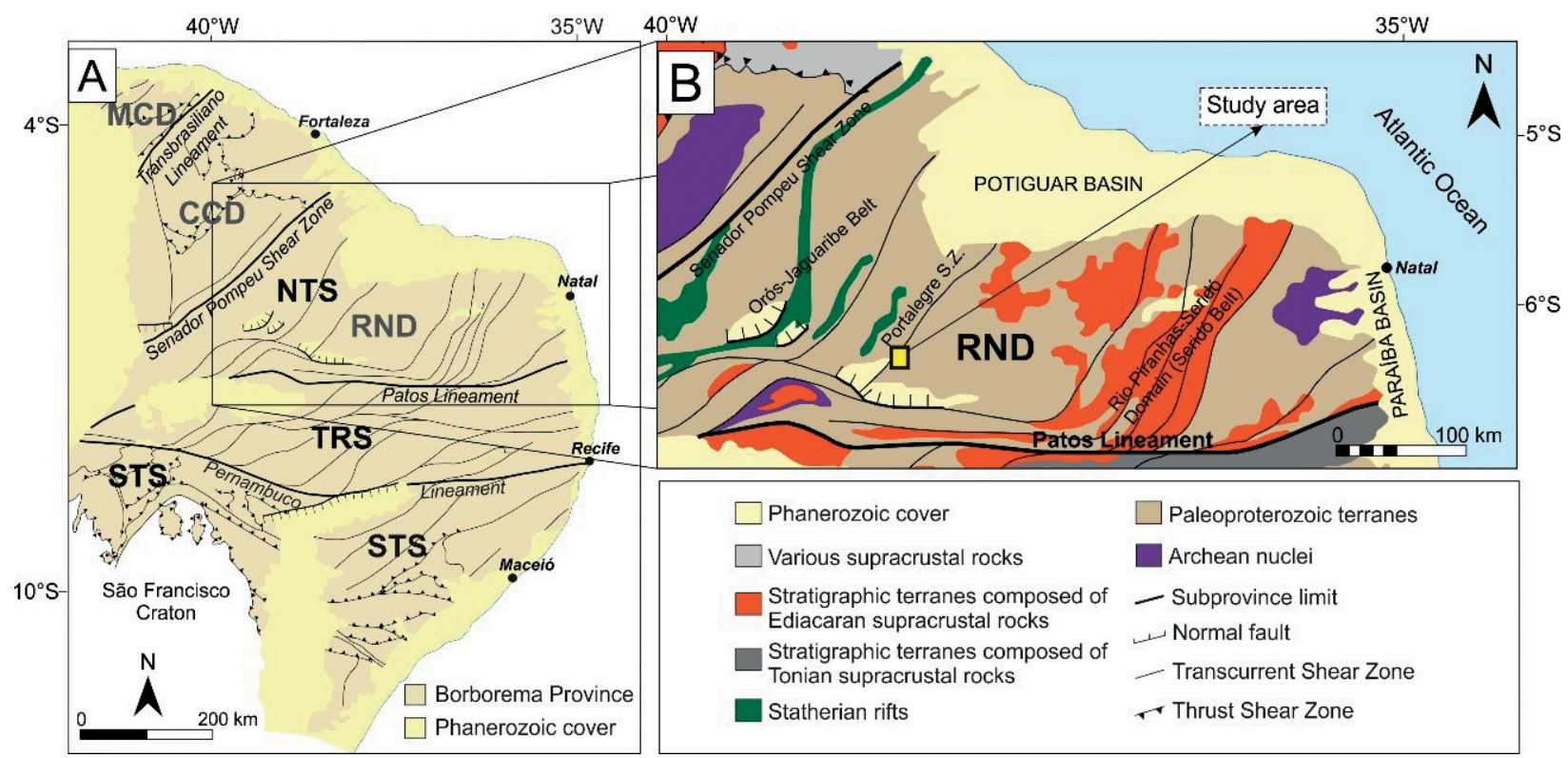

Figure 1. (A) Tectonic Division of the Borborema Province. (B) Schematic geologic map of the Northern sub-province and the location of the studied area. MCD: Médio Coreaú domain; CCD: Ceará Central; RND: Rio Grande do Norte domain; NTS: Northern Sub-province; TRS: Sub-province Transversal; STS: Sub-province South. Modified from Santos et al. (2014) with subdivisions according to Van Schmus et al. (2011). 
high-K calc-alkaline orthogneisses, ranging in composition from diorite to granite containing mafic enclaves and elongated amphibolite bodies (Meunier 1964, Ferreira \& Albuquerque 1969). According to Souza et al. (2007) the Caicó orthogneisses were generated by melting of a metasomatically enriched spinel- to garnet-bearing lherzolite in a subduction zone setting.

The Rhyacian Poço da Cruz Suite (2,172 $\pm 24 \mathrm{Ma}$; Hollanda et al. 2011, Sá et al.2014) is composed of syenogranitic augen gneisses, with K-feldspars porphyroclasts and lenses of dioritic composition. The studied area comprises a NE-trending elongate body, intruded into the Caicó Complex at the south of the Lastro Shear Zone.

The Serra Negra granitoids is formed by four NE-trending plutons of different sizes, whose emplacement were controlled by the dextral kinematic Lastro and Vieirópolis shear zones (Araújo Neto et al. 2018; Fig. 2). These granitoids are medium to coarse-grained, porphyritic, with K-feldspar phenocrysts enclosing quartz and plagioclase crystals, and compositions ranging from quartz monzonite to syenite (Fig. 3A). The plagioclase is presented as subhedral crystals, some of them showing lamellar deformation. Anhedral quartz crystals showed undulatory extinction. Biotite and calcic amphiboles (Fig. 3B) are the principal mafic mineral phases and occur in modal concentrations of $7.0-1.0 \%, 23-3.5 \%$ respectively. Titanite, epidote and magnetite (Fig. $3 \mathrm{C}$ ) are the main accessory phases. The diorite and porphyritic granite enclaves are angular in shape. Some of them enclose rounded amphibole clots, and some show evidence of partial melting (Fig. 3D).

The Serra Branca pluton is intruded into the NE-trending Serra Negra pluton. Both plutons intrude the Paleoproterozoic orthogneisses and migmatites of the Caicó Complex. The Serra Branca pluton is composed of medium grained monzogranites to quartz monzonites (Fig. 4A) and it is the host rocks of the Vieirópolis pegmatites. Amphibole, pyroxene \pm biotite are the main mafic mineral phases, with modal percentage varying from 10 to $20 \%$. Anhedral quartz crystals showed undulose extinction. Pyroxene occurs as subhedral to anhedral crystals. Amphibole occurs as subhedral isolated crystals or replacing pyroxene (Fig. 4B). Epidote, allanite, titanite, apatite and opaque minerals constitute the accessory phases. Euhedral to anhedral magnetite crystals makes up the main opaque minerals. Under reflected light, the magnetite shows pinkish gray color with white rims (Fig. 4C). At the contact with the pegmatites, the Serra Branca granites are fine grained, showing higher concentration of mafic minerals and, less frequently, portions of quartz and plagioclase with saccharoidal texture (Fig. 4D). These features may suggest differences in temperature and magmatic fluid percolation during the emplacement of the pegmatite.

$\mathrm{U}-\mathrm{Pb}$ TIMS zircon ages were reported by Medeiros et al. (2005) at $571 \pm 3 \mathrm{Ma}$ for granitoids correlated to the Serra Negra granites and at $541 \pm 4 \mathrm{Ma}$ to granitoids correlated to the Serra Branca granites.

The pegmatites in the Vieirópolis field comprise four dykes of amazonite-bearing NYF- type pegmatites, hosted by the Serra Branca granite (Fig. 2). Within these pegmatite bodies, the Serra Branca amazonite pegmatite is distinct from other pegmatites of the Vieirópolis pegmatite field and from other well-known pegmatites of the BP by the presence of amazonite megacrysts, which can reach up to $2 \mathrm{~m}$ of length.

The Serra Branca amazonite pegmatite constitutes an $800 \mathrm{~m}$ long, NW- trending dipping $45^{\circ}$ to WSW dyke. Two zones were identified:

- the amazonite zone;

- the albite zone.

The amazonite zone commonly occurs at the top of the pegmatite, and the albite zone in the bottom (Fig. 5A). The contacts between the two zones are irregular, complex and usually characterized by the presence of elongated quartz and patches of small biotite crystals. The main mineral phases of the amazonite zone are large amazonite crystals and quartz. The amazonite is prismatic and euhedral to subhedral, varying

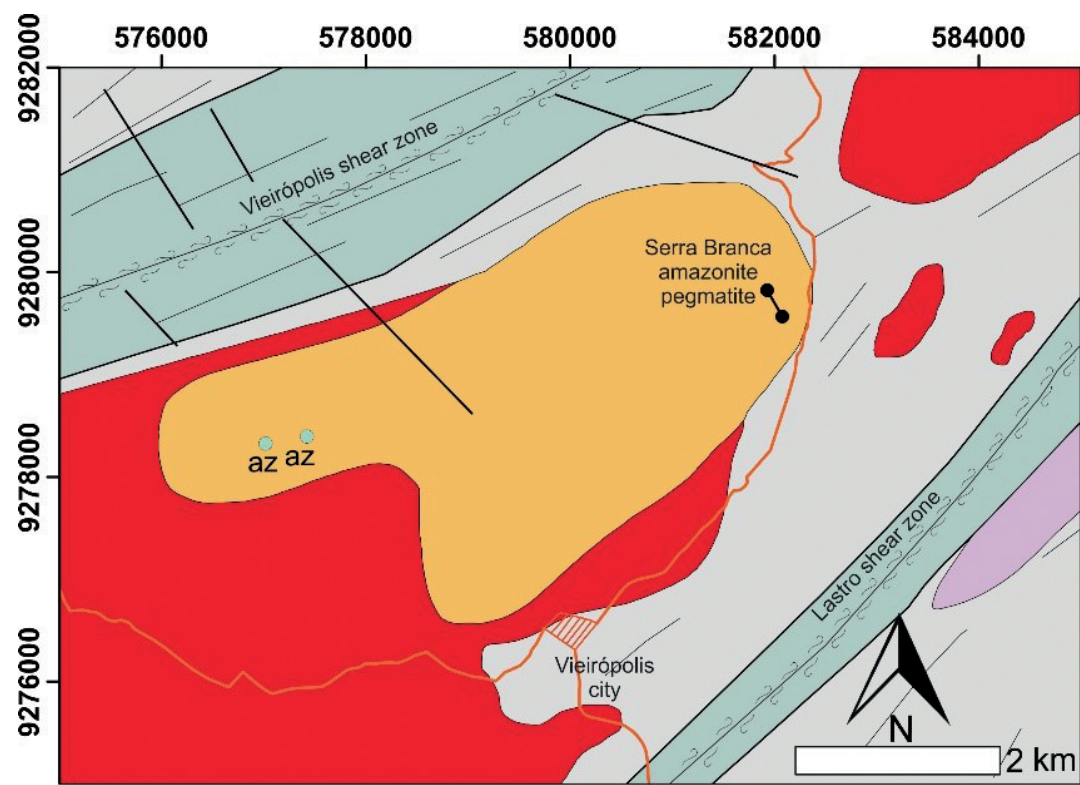

Geological Conventions
SERRA BRANCA GRANITE
$\square \begin{aligned} & \text { Medium- to fine-grained quartz-monzonites } \\ & \text { to quartz-monzodiorites }\end{aligned}$
SERRA NEGRA GRANITE
$\square$ Porphyritic monzodiorites to syenites
POÇO DA CRUZ SUITE
$\square$ Syenogranitic augen gneisses
CAICÓ COMPLEX
$\square$ Orthogneisses, migmatized gneisses and
migmatites
$\square$ Protomylonites to ultramylonites
$\square$ Dyke
$\square$ Fracture
$\simeq$ Regional foliation line
$\square$ Dextral transcurrent shear zone

Figure 2. Geologic simplified map of the Vieirópolis pegmatitic field. Modified from Araújo Neto et al. (2018). 
from centimeter to meter in size and showing bluish green color (Fig. 5B), perthitic exsolution and sometimes graphic texture. The quartz occurs as euhedral to subhedral crystals, with the larger crystals displaying a pseudo-hexagonal habit, with color varying from smoky to colorless (Fig. 5B). The amazonite megacrysts are fractured, and the fractures, as well as the contacts between the amazonite and quartz, are filled up with saccharoidal and/or platy white albite (cleavelandite) and quartz. In this zone, occur a large variety of accessory minerals. Biotite is the most abundant accessory mineral phase appearing as black plates up to $10 \mathrm{~cm}$ long, without a preferential direction (Fig. 5C). Sulphides (galena and aikinite) have centimeter to decimeter irregular cluster (Fig. 5D). Chalcocite was recorded as intergrowths in the galena cleavages (Fig. 5E). Small cavities with diameters up to $0.5 \mathrm{~cm}$ are commonly filled up with pyromorphite, cerussite, bismutite and anglesite. Another cavity-type with secondary minerals was found in the central part of the amazonitic zone filled with fluorite, muscovite, helvine, phenakite, biotite, ilmenite, pyromorphite, rutile, pyrochlore, montmorillonite and illite. Helvine occurs as centimeter crystals enclosed by amazonite (Fig. 5F). The ilmenite occurs as centimeter anhedral crystals disseminated between the amazonite and quartz megacrystals.

The albite zone is composed mainly of saccharoidal whitish albite, hyaline quartz and less frequent cleavelandite (Fig. 5B).
Rare centimeter fractured amazonite crystals and pseudo hexagonal smoky quartz crystals are recorded in the albite zone. The fractures in the amazonite and quartz crystals are filled with saccharoidal albite and quartz. Biotite, ilmenite, zircon, Mn-columbite, spessartite and pyrochlore minerals make up the accessory phases.

\section{MINERAL CHEMISTRY}

Plagioclase, K-feldspar, biotite, amphibole, titanite and opaque minerals were analyzed from 11 samples, using a JEOL JXA-8230 model electronic microprobe equipment, equipped with five WDS and one EDS spectrometers at the Microprobe Laboratory of the Universidade de Brasília. For major elements analyses, they were used an acceleration voltage of $15 \mathrm{~V}$, a current of $10 \mathrm{nA}$ and an electronic bin in the order of $\mu \mathrm{m}$. For analyses of rare earth elements (REE) in titanite, they were used an acceleration voltage of $20 \mathrm{~V}$ and a current of $20 \mathrm{nA}$. The used international standards were REEoxide synthetic glass. The WDS REE corrections followed the Williams (1996) recommendations.

\section{Biotite}

Biotite was analyzed from the Serra Branca (45 crystals) and Serra Negra (30 crystals) granitoids and from the
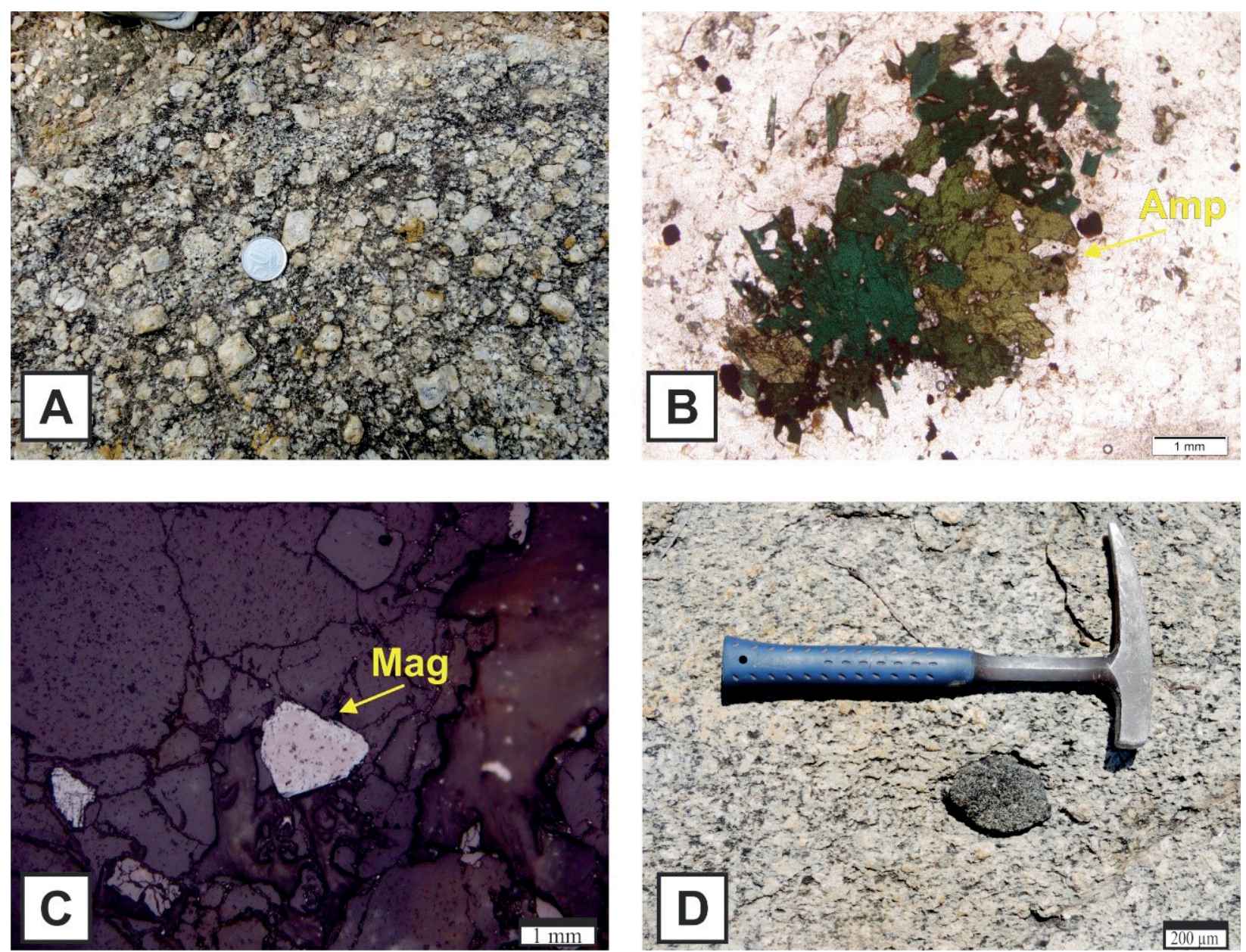

Figure 3. Field and microscopic aspects of the Serra Negra granites; (A) Porphyritic texture with K-feldspar phenocrysts; (B) Clots of amphibole (Amp); (C) Subhedral crystal of magnetite (Mag) under reflected light; (D) Igneous mafic enclaves. 
Serra Branca pegmatite ( 3 crystals), totaling 78 analyses. The results are shown in Table 1 . Biotite analyzed from the Serra Negra granites show $\mathrm{Fe} \#[\mathrm{Fe} /(\mathrm{Fe}+\mathrm{Mg})]$ values ranging from 0.404 to 0.356 , which are like those recorded in biotite from the Serra Branca amazonite pegmatite (Fig. 6A). The biotite from the Serra Branca granitoids shows higher $\mathrm{Fe} \#$ values (0.591 to 0.499). In the $\mathrm{Al}^{\mathrm{IV}}$ versus $\mathrm{Fe}$ diagram (Fig. 6A), the biotites analyzed from the Serra Branca and Serra Negra granitoids show compositions between annite and phlogopite, while biotite analyzed from the Serra Branca amazonite pegmatite are plotting close to the phlogopite field. In the diagram proposed by Nachit et al. (1985), the biotite analyzed from the Serra Negra granitoids plot in the field of those biotites from granitoids of the subalkaline series while the analyzed biotite crystals from the Serra Branca granitoids plot dominantly within the field of biotites from granitoids of alkaline series (Fig. 6B).

\section{Amphibole}

Forty-six and forty-seven amphibole crystals were analyzed from the Serra Negra and Serra Branca granitoids, respectively. The results are shown in Table 2. According to Czamanske and Wones (1973), Si versus $(\mathrm{Na}+\mathrm{K}+\mathrm{Ca})$ discriminates magmatic amphiboles from that tardi- to post magmatic. The amphiboles analyzed from the Serra Negra and Serra Branca granitoids have composition falling in both fields (Fig. 7A). According to the diagram for amphibole discrimination from Leake et al. (1997), the magmatic amphiboles of the Serra Negra granite show composition ranging from ferro-edenite to ferropargasite (Fig. 7B), while the tardi- to post magmatic amphiboles have composition ranging from edenite to $\mathrm{Mg}$-hornblende (Fig. 7C). The magmatic amphiboles from the Serra Branca granites are edenite and tardi to post-magmatic amphiboles are actinolite (Fig. 7B and 7C).

The magmatic amphiboles from both studied granites have low $\mathrm{Fe} \#(\mathrm{Fe} /(\mathrm{Fe}+\mathrm{Mg})$ values suggesting crystallization under high $\mathrm{fO}_{2}$ (Fig. 7D). However, the magmatic amphiboles from the Serra Negra granites have Fe\# values (0.424 to 0.663) slight higher than those analyzed from the Serra Branca granites (0.478 a 0.533 ), reflecting the simultaneous crystallization of biotite and amphibole during the cooling of the Serra Branca granitic magma, and an early crystallization of amphibole in the Serra Negra granitic magmas.

\section{Feldspars}

Eighty-eight feldspar grains, including plagioclase $(\mathrm{Pl})$ and K-feldspars (Kfs), were analyzed from the Serra Negra $(\mathrm{Kfs}=14$ and $\mathrm{Pl}=15$ crystals $)$ and Serra Branca $(\mathrm{Kfs}=7$ and
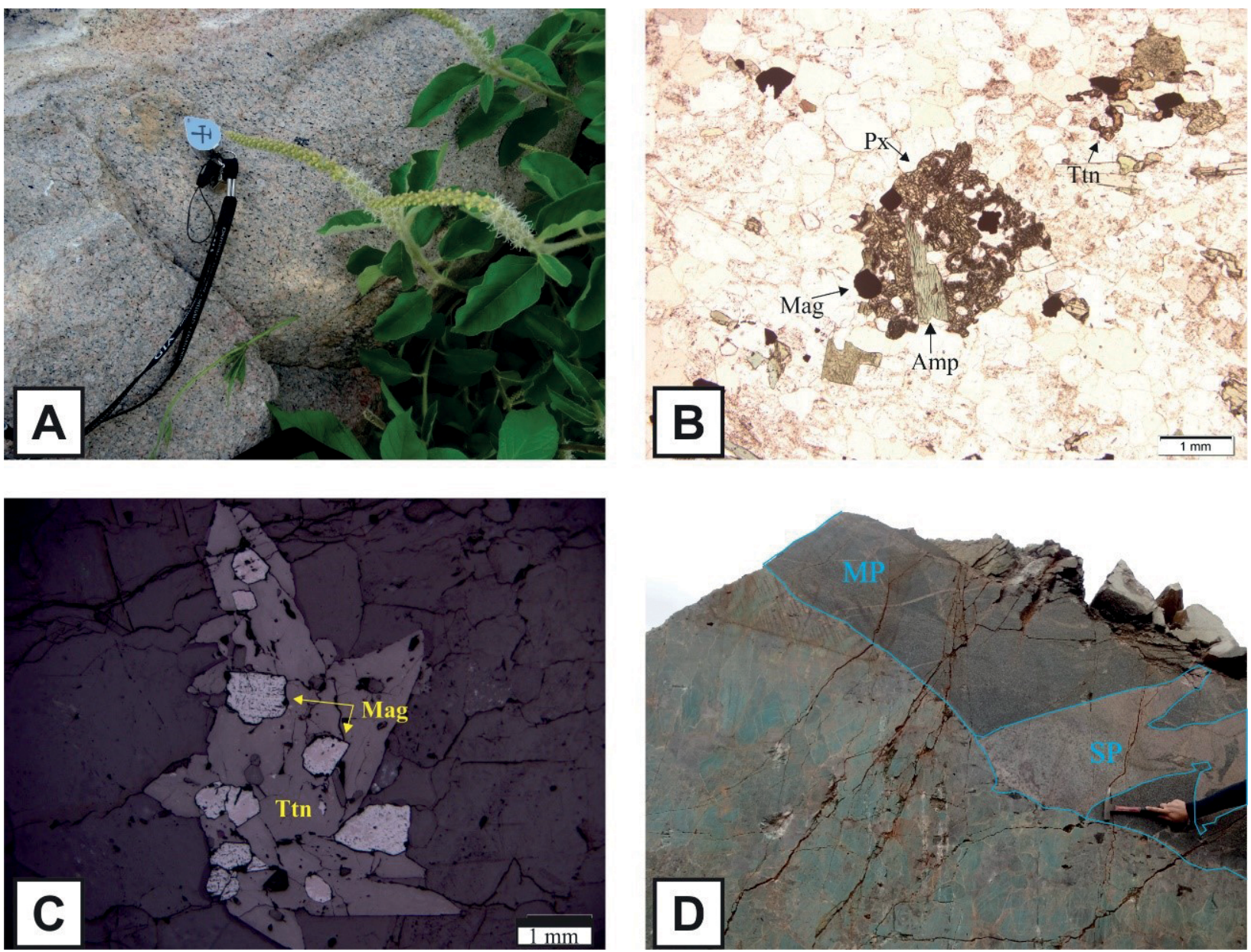

Figure 4. Field and petrographic aspects of the Serra Branca granite: (A) Medium grained Serra Branca granite in situ exhibiting greyish color; (B) lot of amphibole (Amp) and magnetite (Mag) replacing pyroxene (Px); (C) Magnetite crystals (Mag) included by titanite (Tit) under reflected light; (D) The contact between the Serra Branca granite and the Serra Branca amazonite pegmatite showing concentration of mafics along the contact (MP) and portion of saccharoidal texture (SP). 
$\mathrm{Pl}=29$ crystals) granites and Serra Branca amazonite pegmatite $(\mathrm{Kfs}=23$ crystals $)$. Representative results are presented in Table 3.

Plagioclases of the Serra Branca granites have albitic composition $\left(\sim \mathrm{An}_{6} \mathrm{Ab}_{93} \mathrm{Or}_{1}\right)$, while the plagioclase from the Serra Negra granites have composition ranging from oligoclase to albite $\left(\mathrm{An}_{0,5} \mathrm{Ab}_{99} \mathrm{Or}_{0,5}-\mathrm{An}_{11} \mathrm{Ab}_{88} \mathrm{Or}_{1}\right)$.

The K-feldspars from the Serra Negra and Serra Branca granites show similar compositions, ranging from $\mathrm{An}_{0} \mathrm{Ab}_{5} \mathrm{Or}_{95}$ to $\mathrm{An}_{0} \mathrm{Ab}_{7} \mathrm{Or}_{93}$ (Fig. 8A). However, the trace element compositions show significant distinctions: the K-feldspars of the Serra Branca granites show higher Ba contents $(72-4,400 \mathrm{ppm})$ compared to the feldspars from the Serra Negra granites $(\sim 3,400 \mathrm{ppm})$ and the Serra Branca amazonite pegmatite ( $\sim 47 \mathrm{ppm})$. The alkali feldspars from the Serra Branca granite and pegmatite have similar Cs contents ( $\sim 940 \mathrm{ppm})$, and higher values compared to the Cs content recorded in the Serra Negra granites ( $660 \mathrm{ppm})$. The amazonites from the Serra Branca amazonite pegmatite show a composition of $\sim \mathrm{An}_{0} \mathrm{Ab}_{5} \mathrm{Or}_{95}$, high $\mathrm{Rb}(\sim 5,212 \mathrm{ppm})$, and
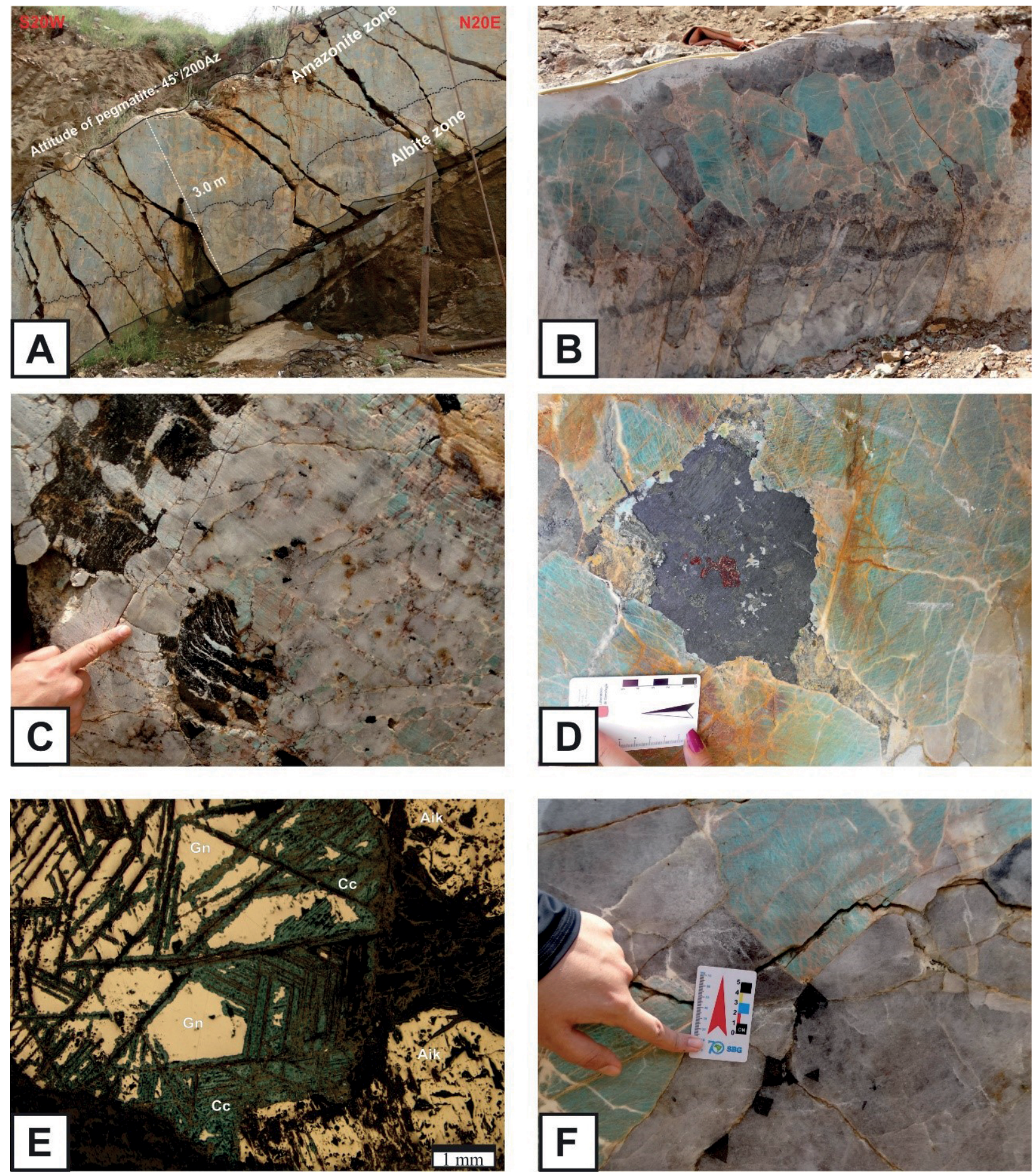

Figure 5. (A) The Serra Branca amazonite pegmatite dyke NW to WSW $/ 45^{\circ}$; (B) Amazonite megacryst and quartz (amazonite zone) above the albite zone, showing irregular contact between them; (C) Biotite in the amazonite zone; (D) Aggregates of sulfides in the amazonite zone; (E) Galena (Gn) showing intergrowths of aikinite (Aik), and chalcocite (Cc) along the cleavage planes. (F) Rectangular and triangulate crystals of helvine hosted by quartz and amazonite megacrysts. 
high to medium $\mathrm{Pb}(3,992$ a $430 \mathrm{ppm})$ contents. Lead content in alkali feldspars is responsible for the bluish green color of the amazonites (Hofmeister \& Rossman 1985, Ostrooumov \& Banerjee 2005).

\section{Opaque minerals}

Thirteen grains of opaque minerals from the Serra Branca granites and nine grains from the Serra Negra granites were analyzed (Tab. 4). The opaque minerals recognized under reflected light from the Serra Negra granites are only magnetite (Fig. 8B), while those from the Serra Branca granites are magnetite (the most abundant; Fig. 4D) and Mn-ilmenite, with $\mathrm{MnO}$ contents varying from 18.81 to $20.23 \mathrm{wt}$.\%. The analyzed magnetite from both plutons has low $\mathrm{Cr}_{2} \mathrm{O}_{3}(<0.18 \mathrm{wt}$.\%) and $\mathrm{V}_{2} \mathrm{O}_{3}(<0.25 \mathrm{wt} . \%)$, similar trace element composition is presented by the Mn-ilmenites of the Serra Branca granites $\left(\mathrm{Cr}_{2} \mathrm{O}_{3}<0.12\right.$ wt.\% e $\mathrm{V}_{2} \mathrm{O}_{3}<0.631$ wt.\% $)$.

\section{Titanite}

Seven titanite crystals from the Serra Branca granites and four grains from the Serra Negra granites were analyzed. The results are shown in Table 5. The titanites from the Serra

Table 1. Chemical composition of biotite from the Serra Branca amazonite pegmatite, Serra Branca and Serra Negra granites.

\begin{tabular}{|c|c|c|c|c|c|c|c|c|}
\hline \multirow{2}{*}{\begin{tabular}{l|} 
Lithotypes \\
Samples
\end{tabular}} & \multicolumn{3}{|c|}{ Serra Branca granite } & \multicolumn{2}{|c|}{ Serra Negra granite } & \multicolumn{3}{|c|}{ Serra Branca amazonite pegmatite } \\
\hline & AMZ 56 & AMZ 74 & AMZ 74A & AMZ 113 & AMZ 114 & AMZ 104P 1 & AMZ 104P 2 & AMZ 104P 3 \\
\hline $\begin{array}{l}\text { Number of points } \\
\text { analyzed }=\mathbf{n}\end{array}$ & $n=6$ & $\mathbf{n}=\mathbf{1 5}$ & $\mathbf{n}=\mathbf{2 7}$ & $\mathbf{n}=\mathbf{5}$ & $\mathbf{n}=\mathbf{1 0}$ & $\mathbf{n}=\mathbf{1}$ & $\mathbf{n}=\mathbf{1}$ & $\mathbf{n}=\mathbf{1}$ \\
\hline $\mathrm{SiO}_{2}($ wt. $\%)$ & 38.82 & 38.77 & 38.61 & 40.18 & 38.02 & 39.06 & 40.26 & 38.25 \\
\hline $\mathrm{TiO}_{2}$ & 1.48 & 2.13 & 2.15 & 1.15 & 1.34 & 1.15 & 1.57 & 1.78 \\
\hline $\mathrm{Al}_{2} \mathrm{O}_{3}$ & 11.21 & 13.13 & 12.38 & 13.74 & 13.02 & 9.25 & 9.97 & 8.95 \\
\hline $\mathrm{FeO}$ & 11.74 & 16.61 & 18.51 & 15.52 & 14.56 & 14.57 & 13.46 & 14.84 \\
\hline $\mathrm{MnO}$ & 0.39 & 2.52 & 2.68 & 0.27 & 0.39 & 1.91 & 1.74 & 2.39 \\
\hline $\mathrm{MgO}$ & 15.33 & 8.85 & 9.95 & 13.36 & 13.00 & 11.98 & 13.15 & 12.28 \\
\hline $\mathrm{CaO}$ & 0.07 & 0.03 & 0.02 & 0.06 & 0.05 & 0.14 & 0.06 & 0.05 \\
\hline $\mathrm{Na}_{2} \mathrm{O}$ & 0.08 & 0.05 & 0.06 & 0.05 & 0.06 & 0.09 & 0.09 & 0.04 \\
\hline $\mathrm{K} 2 \mathrm{O}$ & 9.40 & 8.33 & 9.55 & 8.84 & 9.40 & 8.40 & 9.03 & 8.92 \\
\hline $\mathrm{SrO}$ & 0.00 & 0.00 & 0.00 & 0.00 & 0.00 & 0.00 & 0.00 & 0.00 \\
\hline $\mathrm{BaO}$ & 0.10 & 0.06 & 0.08 & 0.07 & 0.10 & 0.00 & 0.07 & 0.03 \\
\hline $\mathrm{F}$ & 1.96 & 3.09 & 2.90 & 1.43 & 1.51 & 4.76 & 5.25 & 4.76 \\
\hline $\mathrm{Cl}$ & 0.01 & 0.01 & 0.01 & 0.01 & 0.01 & 0.05 & 0.00 & 0.01 \\
\hline $\mathrm{Cr}_{2} \mathrm{O}_{3}$ & 0.05 & 0.02 & 0.04 & 0.03 & 0.04 & 0.05 & 0.00 & 0.00 \\
\hline $\mathrm{NiO}$ & 0.01 & 0.02 & 0.04 & 0.02 & 0.02 & 0.06 & 0.00 & 0.00 \\
\hline $\mathrm{Li}_{2} \mathrm{O}$ & 0.03 & 0.04 & 0.01 & 0.00 & 0.03 & & & \\
\hline $\mathrm{H}_{2}^{2} \mathrm{O}$ & 2.86 & 2.32 & 2.47 & 3.28 & 3.08 & 1.39 & 1.31 & 1.40 \\
\hline Subtotal & 93.71 & 96.58 & 99.53 & 98.17 & 94.82 & 95.14 & 97.71 & 95.60 \\
\hline $\mathrm{O}=\mathrm{F} \cdot \mathrm{Cl}$ & 0.83 & 1.30 & 1.22 & 0.60 & 0.64 & 2.02 & 2.21 & 2.01 \\
\hline Total & 92.88 & 95.28 & 98.30 & 97.56 & 94.18 & 93.13 & 95.50 & 93.59 \\
\hline Si (apfu) & 6.14 & 6.14 & 6.01 & 6.08 & 6.01 & 6.40 & 6.36 & 6.27 \\
\hline $\mathrm{Al}^{4+}$ & 1.86 & 1.86 & 1.99 & 1.92 & 1.99 & 1.60 & 1.64 & 1.73 \\
\hline $\mathrm{Al}^{6+}$ & 0.23 & 0.59 & 0.29 & 0.53 & 0.43 & 0.19 & 0.21 & 0.00 \\
\hline $\mathrm{Ti}$ & 0.18 & 0.25 & 0.25 & 0.13 & 0.16 & 0.14 & 0.19 & 0.22 \\
\hline $\mathrm{Cr}$ & 0.01 & 0.00 & 0.00 & 0.00 & 0.00 & 0.01 & 0.00 & 0.00 \\
\hline $\mathrm{Fe}$ & 1.55 & 2.20 & 2.41 & 1.96 & 1.92 & 2.00 & 1.78 & 2.04 \\
\hline $\mathrm{Mn}$ & 0.05 & 0.34 & 0.35 & 0.03 & 0.05 & 0.26 & 0.23 & 0.33 \\
\hline $\mathrm{Mg}$ & 3.61 & 2.09 & 2.31 & 3.01 & 3.06 & 2.93 & 3.09 & 3.00 \\
\hline $\mathrm{Ni}$ & 0.00 & 0.00 & 0.00 & 0.00 & 0.00 & 0.01 & 0.00 & 0.00 \\
\hline $\mathrm{Cu}$ & 0.00 & 0.00 & 0.00 & 0.00 & 0.00 & 0.01 & 0.00 & 0.00 \\
\hline $\mathrm{Li}$ & 0.02 & 0.02 & 0.01 & 0.00 & 0.02 & 0.00 & 0.00 & 0.00 \\
\hline $\mathrm{Ca}$ & 0.01 & 0.00 & 0.00 & 0.01 & 0.01 & 0.03 & 0.01 & 0.01 \\
\hline $\mathrm{Na}$ & 0.03 & 0.02 & 0.02 & 0.01 & 0.02 & 0.03 & 0.03 & 0.01 \\
\hline $\mathrm{K}$ & 1.90 & 1.68 & 1.90 & 1.71 & 1.89 & 1.76 & 1.82 & 1.87 \\
\hline $\mathrm{Sr}$ & 0.00 & 0.00 & 0.00 & 0.00 & & 0.00 & 0.00 & 0.00 \\
\hline $\mathrm{Ba}$ & 0.01 & 0.00 & 0.01 & 0.00 & 0.01 & 0.00 & 0.00 & 0.00 \\
\hline $\mathrm{OH}$ & 3.02 & 2.45 & 2.57 & 3.32 & 3.24 & 1.52 & 1.38 & 1.53 \\
\hline $\mathrm{F}$ & 0.98 & 1.55 & 1.43 & 0.68 & 0.76 & 2.47 & 2.62 & 2.47 \\
\hline $\mathrm{Cl}$ & 0.00 & 0.00 & 0.00 & 0.00 & 0.00 & 0.01 & 0.00 & 0.00 \\
\hline Total & 19.61 & 19.27 & 19.56 & 19.43 & 19.60 & 19.55 & 19.53 & 19.67 \\
\hline $\mathrm{Al}^{\text {total }}$ & 2.09 & 2.45 & 2.27 & 2.45 & 2.42 & 1.79 & 1.85 & 1.73 \\
\hline $\mathrm{Fe} / \mathrm{Fe}+\mathrm{Mg}$ & 0.30 & 0.51 & 0.51 & 0.39 & 0.39 & 0.41 & 0.36 & 0.40 \\
\hline
\end{tabular}

apfu: atom per formula unit. 

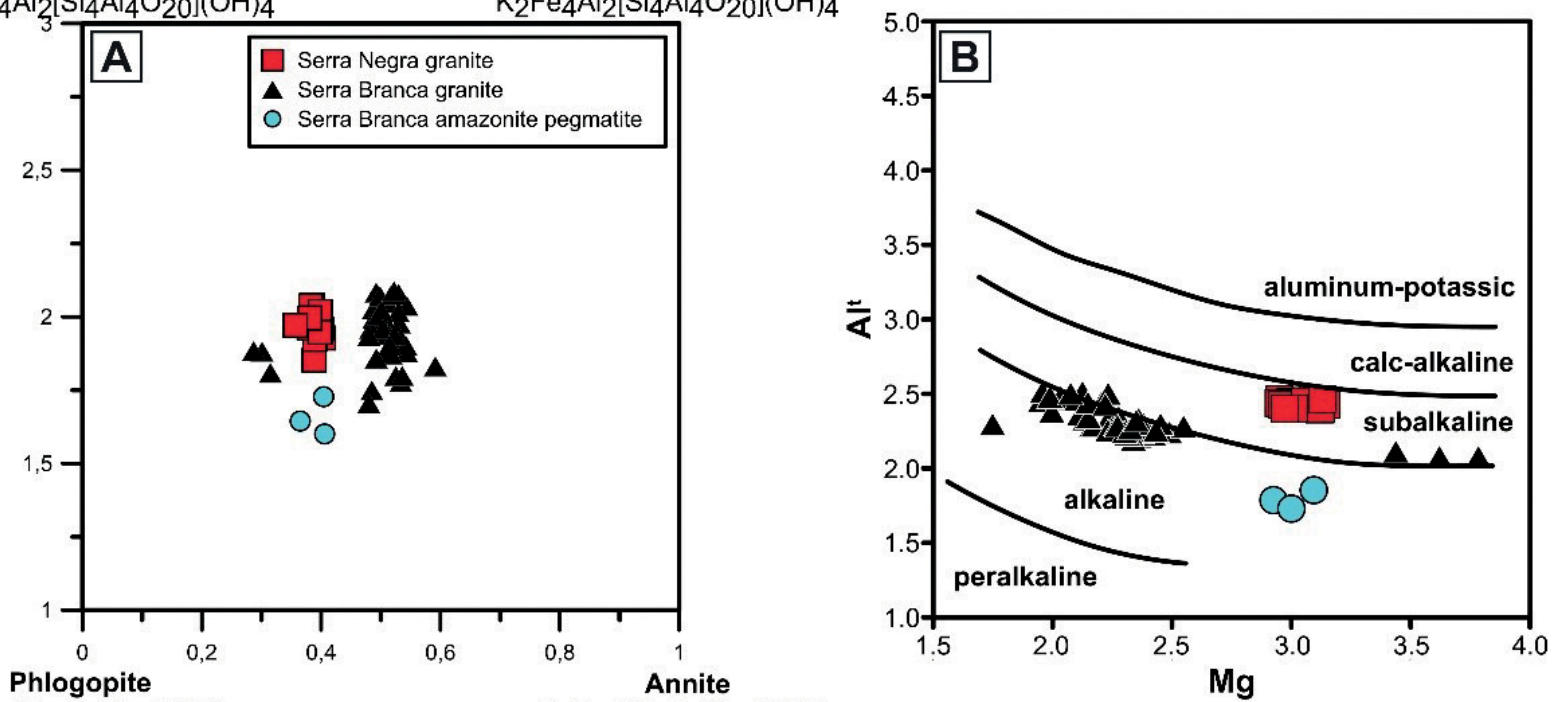

$\mathrm{K}_{2} \mathrm{Mg}_{6}\left[\mathrm{Si}_{6} \mathrm{Al}_{2} \mathrm{O}_{20}\right](\mathrm{OH})_{4}$

$\mathrm{K}_{2} \mathrm{Fe}_{6}\left[\mathrm{Si}_{6} \mathrm{Al}_{2} \mathrm{O}_{20}\right](\mathrm{OH})_{4}$

Figure 6. Biotite classification diagrams: (A) Fe\# vs. $\mathrm{Al}^{\mathrm{IV}}$ diagram from Deer (1992); B) Mg vs. Al ${ }^{\mathrm{IV}}$ diagram from Nachit et al. (1985).

Table 2. Amphibole chemical composition of the Serra Branca and Serra Negra granites.

\begin{tabular}{|c|c|c|c|c|c|c|c|c|}
\hline \multirow{3}{*}{\begin{tabular}{|l} 
Lithotypes \\
Type \\
Samples \\
\end{tabular}} & \multicolumn{3}{|c|}{ Serra Branca granite } & \multicolumn{5}{|c|}{ Serra Negra granite } \\
\hline & \multirow{2}{*}{$\begin{array}{c}\begin{array}{c}\text { Magmatic } \\
\text { amphibole }\end{array} \\
\text { AMZ 55 } \\
\end{array}$} & \multicolumn{2}{|c|}{$\begin{array}{c}\text { Non magmatic } \\
\text { amphibole }\end{array}$} & \multicolumn{3}{|c|}{$\begin{array}{l}\text { Magmatic } \\
\text { amphibole }\end{array}$} & \multicolumn{2}{|c|}{$\begin{array}{l}\text { Non magmatic } \\
\text { amphibole }\end{array}$} \\
\hline & & Amz 55 & Amz 56 & AMZ 111 & AMZ 113 & AMZ 114 & AMZ 113 & AMZ114 \\
\hline $\begin{array}{l}\text { Number of points } \\
\text { analyzed }=\mathbf{n}\end{array}$ & $\mathrm{n}=19$ & $n=13$ & $\mathrm{n}=\mathbf{2 4}$ & $\mathrm{n}=18$ & $\mathbf{n}=\mathbf{1}$ & $\mathbf{n}=\mathbf{1}$ & $\mathbf{n}=\mathbf{1 2}$ & $\mathbf{n}=\mathbf{1 7}$ \\
\hline $\mathrm{SiO}_{2}$ (wt.\%) & 45.11 & 50.01 & 52.97 & 41.37 & 47.10 & 47.12 & 49.39 & 46.28 \\
\hline $\mathrm{TiO}_{2}$ & 0.15 & 0.12 & 0.17 & 0.23 & 0.92 & 0.86 & 0.41 & 0.59 \\
\hline $\mathrm{Al}_{2} \mathrm{O}_{3}$ & 7.03 & 3.09 & 1.64 & 8.87 & 7.09 & 6.41 & 6.35 & 6.71 \\
\hline $\mathrm{MnO}$ & 0.87 & 0.83 & 0.56 & 0.92 & 0.56 & 0.45 & 0.52 & 0.45 \\
\hline $\mathrm{FeO}$ & 19.48 & 15.11 & 9.74 & 22.99 & 15.34 & 15.23 & 15.26 & 14.23 \\
\hline $\mathrm{MgO}$ & 10.49 & 10.07 & 13.15 & 7.25 & 10.85 & 11.59 & 11.74 & 11.92 \\
\hline $\mathrm{CaO}$ & 11.16 & 17.38 & 16.72 & 11.52 & 11.23 & 11.46 & 11.47 & 10.28 \\
\hline $\mathrm{Na}_{2} \mathrm{O}$ & 1.59 & 1.47 & 1.61 & 1.43 & 1.53 & 1.36 & 1.27 & 1.11 \\
\hline $\mathrm{PbO}$ & 0.02 & 0.06 & 0.02 & 0.03 & 0.09 & 0.05 & 0.02 & 0.02 \\
\hline $\mathrm{K}_{2} \mathrm{O}$ & 1.32 & 0.52 & 0.21 & 1.46 & 0.79 & 0.86 & 0.73 & 1.75 \\
\hline $\mathrm{F}$ & 1.09 & 0.42 & 0.26 & 0.54 & 0.51 & 0.70 & 0.52 & 0.69 \\
\hline $\mathrm{Cl}$ & 0.01 & 0.01 & 0.01 & 0.01 & 0.02 & 0.00 & 0.01 & 0.01 \\
\hline Total & 98.33 & 99.06 & 97.07 & 96.61 & 96.02 & 96.08 & 97.69 & 94.05 \\
\hline $\mathrm{Si}$ (apfu) & 6.84 & 7.43 & 7.75 & 6.50 & 7.13 & 7.14 & 7.30 & 7.15 \\
\hline $\mathrm{Al}^{4+}$ & 1.15 & 0.46 & 0.20 & 1.50 & 0.87 & 0.86 & 0.70 & 0.85 \\
\hline $\mathrm{Ti}$ & 0.02 & 0.03 & 0.02 & 0.03 & 0.11 & 0.10 & 0.05 & 0.07 \\
\hline $\mathrm{Al} \mathrm{VI}$ & 0.11 & 0.24 & 0.19 & 0.15 & 0.40 & 0.29 & 0.41 & 0.39 \\
\hline $\mathrm{Fe}^{3+}$ & 0.47 & 0.23 & 0.06 & 0.62 & 0.00 & 0.04 & 0.08 & 0.01 \\
\hline $\mathrm{Fe}^{2+}$ & 2.00 & 1.82 & 1.19 & 2.40 & 1.94 & 1.89 & 1.83 & 1.70 \\
\hline $\mathrm{Mg}$ & 2.37 & 2.23 & 2.87 & 1.70 & 2.45 & 2.62 & 2.59 & 2.75 \\
\hline $\mathrm{Mn}^{2+}$ & 0.11 & 0.18 & 0.09 & 0.12 & 0.00 & 0.06 & 0.07 & 0.08 \\
\hline $\mathrm{Ca}$ & 1.81 & 1.92 & 1.91 & 1.94 & 1.82 & 1.86 & 1.82 & 1.69 \\
\hline $\mathrm{Na}$ & 0.10 & 0.10 & 0.20 & 0.03 & 0.18 & 0.13 & 0.17 & 0.08 \\
\hline $\mathrm{Na}$ & 0.37 & 0.39 & 0.37 & 0.40 & 0.27 & 0.27 & 0.19 & 0.29 \\
\hline $\mathrm{Pb}$ & 0.00 & 0.00 & 0.00 & 0.00 & 0.00 & 0.00 & 0.00 & 0.00 \\
\hline $\mathrm{K}$ & 0.26 & 0.13 & 0.05 & 0.29 & 0.15 & 0.17 & 0.14 & 0.36 \\
\hline $\mathrm{OH}$ & 1.47 & 1.79 & 1.87 & 1.73 & 1.75 & 1.67 & 1.75 & 1.66 \\
\hline $\mathrm{F}$ & 0.53 & 0.53 & 0.27 & 0.27 & 0.24 & 0.33 & 0.24 & 0.34 \\
\hline $\mathrm{Cl}$ & 0.00 & 0.00 & 0.00 & 0.00 & 0.00 & 0.00 & 0.00 & 0.00 \\
\hline Cations ${ }^{t}$ & 17.63 & 17.49 & 17.04 & 17.68 & 17.32 & 17.41 & 17.34 & 17.42 \\
\hline
\end{tabular}

Apuf $=$ atoms per formula unit. 
Negra granites show $\mathrm{Al}_{2} \mathrm{O}_{3}$ ranging from 1.62 to $1.20 \mathrm{wt}$.\%, slightly higher than those recorded in titanites analyzed from the Serra Branca granites (0.87 to $1.25 w t . \%$ ).

The titanite REE patterns, normalized to the chondrite (Nakamura 1974), are shown in Figure 9. The titanite from the Serra Negra Pluton is light rare earth elements (LREE) enriched compared to the titanite from the Serra Branca granites. In the La versus $\mathrm{Sm}$ (Fig. 10A) and Ce versus $\mathrm{Yb}$ (Fig. 10B) diagrams, the titanite from the Serra Branca granites shows lower $\mathrm{Ce}$ and $\mathrm{Sm}$ contents and similar La and $\mathrm{Yb}$ contents, compared to those of the Serra Negra granites.

\section{CRYSTALLIZATION CONDITIONS}

The crystallization conditions (pressure, temperature and oxygen fugacity) were determined using petrography, mineral chemistry and $\mathrm{Zr}$ contents in whole-rock geochemistry (Tab. 6). Magmatic amphibole (Czamanske \& Wones 1973) and plagioclase in equilibrium with magmatic amphibole were used to define crystallization conditions.

\section{Amphibole geothermobarometry}

Studies carried on the paragenesis of calcic amphibole in mafic (meta-) igneous rocks (Spear 1981, Mader \& Berman 1992, Ague \& Brandon 1992, Ague 1997, Ernst \& Liu 1998, Tulloch \& Challis 2000) showed that with increasing pressure-temperature $(\mathrm{P}-\mathrm{T})$ conditions, calcic amphiboles exhibit an increase in $\mathrm{Mg} /(\mathrm{Mg}+\mathrm{Fe})$ and $\mathrm{K}, \mathrm{Al}, \mathrm{Na}$, and $\mathrm{Ti}$ contents and a decrease in $\mathrm{Si}$ and total $\mathrm{Fe}+\mathrm{Mg}+\mathrm{Mn}+\mathrm{Ca}$. Pressure conditions of crystallization, deduced from contact aureoles or experimentally controlled runs, are linearly correlated with the $\mathrm{Al}_{t}$ content in magmatic amphibole. Many calibrations of the Al-in-amphibole barometer have been published (Hollister et al. 1987, Johnson \& Rutherford 1988, Rutter et al. 1989, Blundy \& Holland 1990, Schmidt 1992, Anderson \& Smith 1995, Ernst \& Liu 1998), since the pioneer work of Hammarstrom and Zen (1986).

Table 3. Feldspars composition of the Serra Branca amazonite pegmatite, Serra Branca and Serra Negra granites.

\begin{tabular}{|c|c|c|c|c|c|}
\hline \multirow[t]{2}{*}{ Lithotypes } & $\begin{array}{c}\text { Serra } \\
\text { Branca } \\
\text { granite }\end{array}$ & $\begin{array}{c}\text { Serra } \\
\text { Negra } \\
\text { granite }\end{array}$ & $\begin{array}{c}\text { Serra } \\
\text { Branca } \\
\text { amazonite } \\
\text { pegmatite }\end{array}$ & $\begin{array}{c}\text { Serra } \\
\text { Branca } \\
\text { granite }\end{array}$ & $\begin{array}{c}\text { Serra } \\
\text { Negra } \\
\text { granite }\end{array}$ \\
\hline & \multicolumn{3}{|c|}{ Alkali Feldspar } & \multicolumn{2}{|c|}{ Plagioclase } \\
\hline $\mathrm{SiO}_{2}$ (wt.\%) & 65.08 & 64.48 & 64.90 & 68.22 & 66.89 \\
\hline $\mathrm{Al}_{2} \mathrm{O}_{3}$ & 17.27 & 17.06 & 16.81 & 18.99 & 20.59 \\
\hline $\mathrm{FeO}$ & 0.08 & 0.03 & 0.13 & 0.17 & 0.07 \\
\hline $\mathrm{CaO}$ & 0.01 & 0.01 & 0.01 & 1.05 & 2.46 \\
\hline $\mathrm{Na}_{2} \mathrm{O}$ & 0.73 & 0.52 & 0.59 & 10.75 & 10.12 \\
\hline $\mathrm{K}_{2} \mathrm{O}$ & 15.43 & 15.58 & 15.40 & 0.16 & 0.15 \\
\hline Total & 99.44 & 98.40 & 98.76 & 99.75 & 100.50 \\
\hline \multicolumn{6}{|c|}{ Trace elements in ppm } \\
\hline $\mathrm{PbO}$ & 259.9 & 433.1 & 606.4 & 259.9 & 0.0 \\
\hline $\mathrm{Cs}_{2} \mathrm{O}$ & 943.2 & 660.3 & 943.2 & 848.9 & 0.0 \\
\hline $\mathrm{Rb}_{2} \mathrm{O}$ & 0.0 & 91.4 & 5212.1 & 0.0 & 0.0 \\
\hline $\mathrm{BaO}$ & 4388.7 & 3493.1 & 447.8 & 358.3 & 358.3 \\
\hline An & 0.02 & 0.07 & 0.05 & 6.04 & 11.74 \\
\hline $\mathrm{Ab}$ & 7.22 & 4.83 & 5.46 & 93.01 & 87.43 \\
\hline Or & 92.77 & 95.10 & 94.48 & 0.90 & 0.83 \\
\hline
\end{tabular}
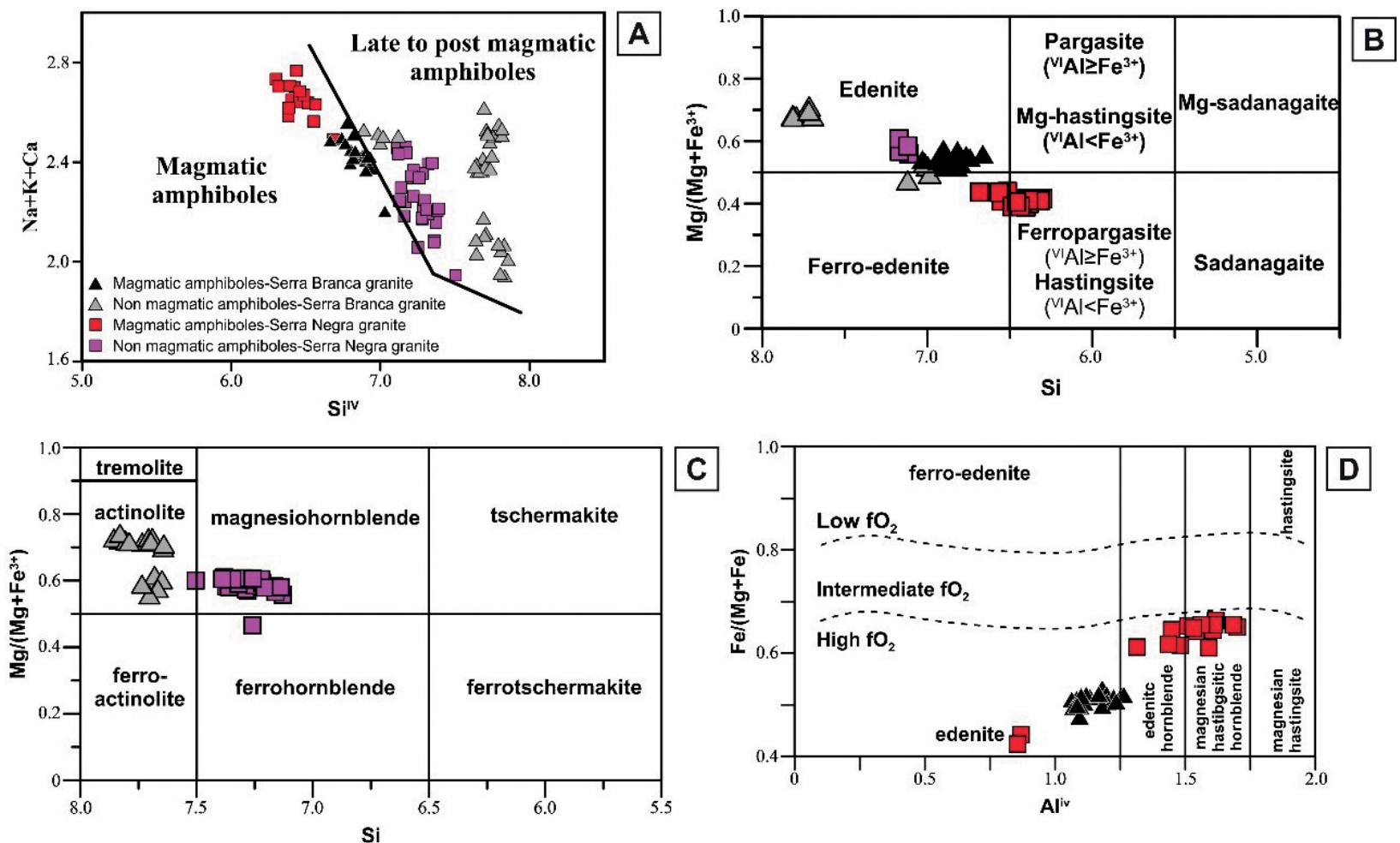

Figure 7. (A) Classification diagram of amphiboles $\mathrm{Si}^{\mathrm{iV}}$ versus $(\mathrm{Na}+\mathrm{K}+\mathrm{Ca})$ with fields defined by Czamanske and Wones (1973); (B) Amphibole classification diagram from Leake et al. (1997); (C) Amphibole classification diagram from Leake et al. (1997); (D) $\mathrm{Al}^{\mathrm{IV}} \mathrm{vs}$ $\mathrm{Fe} /(\mathrm{Mg}+\mathrm{Fe})$ diagram with oxygen fugacity fields of Anderson \& Smith (1995). 


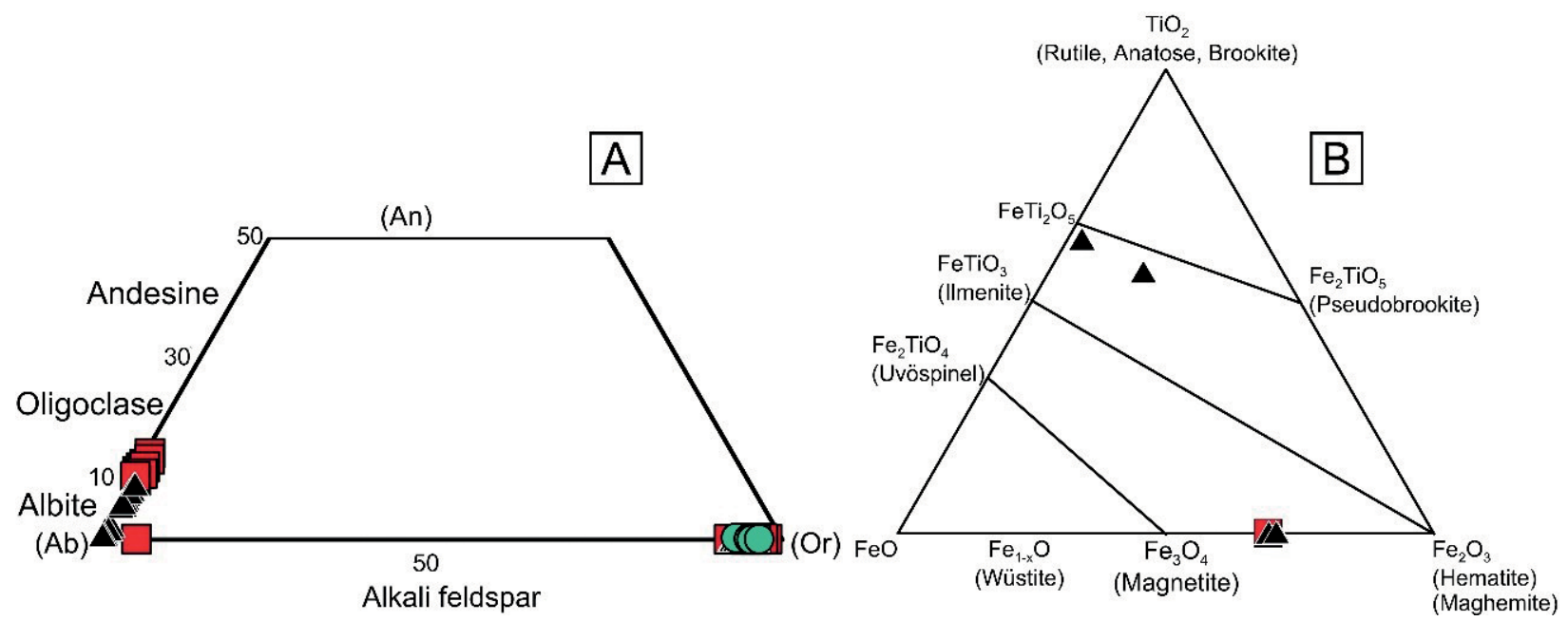

Figure 8. (A) An-Ab-Or ternary diagram for feldspar classification (Deer et al. 1992); (B) $\mathrm{Fe}_{2} \mathrm{O}_{3}$ vs $\mathrm{FeO}$ vs $\mathrm{TiO}_{2}$ ternary diagram for oxides classification from Buddington \& Lindsley (1964).

Table 4. Overall chemical composition of the Serra Branca and Serra Negra granites.

\begin{tabular}{lcc}
\hline Lithotypes & Serra Branca granite & Serra Negra granite \\
\hline $\mathrm{SiO}_{2}($ wt.\% & 30.56 & 30.02 \\
$\mathrm{Al}_{2} \mathrm{O}_{3}$ & 1.16 & 1.63 \\
$\mathrm{~F}$ & 0.77 & 0.72 \\
$\mathrm{TiO}_{2}$ & 35.97 & 36.04 \\
$\mathrm{CaO}$ & 27.53 & 27.79 \\
$\mathrm{FeO}$ & 2.32 & 2.60 \\
$\mathrm{Total}$ & 98.32 & 98.81 \\
\hline \multicolumn{3}{c}{} \\
\hline $\mathrm{Er}_{2} \mathrm{O}_{3}$ & Trace elements in ppm \\
$\mathrm{Tm}_{2} \mathrm{O}_{3}$ & 175 & 262 \\
$\mathrm{Yb}_{2} \mathrm{O}_{3}$ & 175 & 0 \\
$\mathrm{Ho}_{2} \mathrm{O}_{3}$ & 88 & 263 \\
$\mathrm{Lu}_{2} \mathrm{O}_{3}$ & 524 & 436 \\
$\mathrm{Dy}_{2} \mathrm{O}_{3}$ & 88 & 88 \\
$\mathrm{~Tb}_{2} \mathrm{O}_{3}$ & 0 & 349 \\
$\mathrm{Sm}_{2} \mathrm{O}_{3}$ & 0 & 0 \\
$\mathrm{Gd}_{2} \mathrm{O}_{3}$ & 259 & 1,121 \\
$\mathrm{Eu}_{2} \mathrm{O}_{3}$ & 174 & 174 \\
$\mathrm{ThO}_{2}$ & 86 & 345 \\
$\mathrm{Pr}_{2} \mathrm{O}_{3}$ & 281 & 187 \\
$\mathrm{Nd}_{2} \mathrm{O}_{3}$ & 256 & 598 \\
$\mathrm{Ce}_{2} \mathrm{O}_{3}$ & 979 & 1,957 \\
$\mathrm{La}_{2} \mathrm{O}_{3}$ & 2,903 & 2,561 \\
$\mathrm{UO}_{2}$ & 1,023 & 512 \\
$\mathrm{REE}^{\mathrm{T}}$ & 1,587 & 1,763 \\
${ }^{\mathrm{T}}$ & 8,597 & 10,617 \\
\hline
\end{tabular}

Table 5. Titanite chemical composition of the Serra Branca and Serra Negra granites.

\begin{tabular}{lcc}
\hline Lithotypes & Serra Branca granite & Serra Negra granite \\
\hline $\mathrm{Cr}_{2} \mathrm{O}_{3}$ (wt.\%) & 0.09 & 0.04 \\
$\mathrm{Al}_{2} \mathrm{O}_{3}$ & 1.29 & 0.09 \\
$\mathrm{TiO}_{2}$ & 10.59 & 0.05 \\
$\mathrm{FeO}$ & 28.21 & 31.16 \\
$\mathrm{Fe}_{2} \mathrm{O}_{3}$ & 53.19 & 69.68 \\
$\mathrm{MgO}$ & 0.04 & 0.02 \\
$\mathrm{MnO}$ & 4.80 & 0.14 \\
$\mathrm{NiO}$ & 0.01 & 0.00 \\
$\mathrm{~V}_{2} \mathrm{O}_{5}$ & 0.27 & 0.20 \\
Total & 98.48 & 101.40 \\
\hline
\end{tabular}

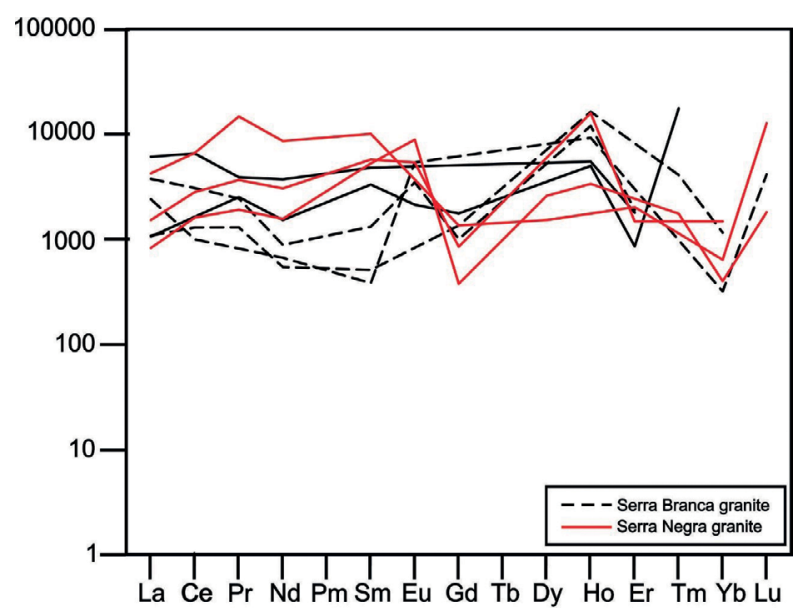

Figure 9. Rare earth elements contents of titanite crystals normalized to the chondrites values of Nakamura (1974).

The buffering equilibrium assemblage: quartz + hornblende + plagioclase (oligoclase or andesine) + K-feldspar + biotite + titanite + magnetite (or ilmenite) is required in calc-alkalic granites, in order to use the total $\mathrm{Al}$-in-hornblende as a pressure crystallization indicator. This assemblage is present in the granites from the studied plutons, except by the albitic composition of the plagioclase recorded in the Serra Branca granites. Only amphibole with $\mathrm{Fe}_{\mathrm{t}} /\left(\mathrm{Fe}_{\mathrm{t}}+\mathrm{Mg}\right)$ ratio $<0.65$ can be used in the in Al-in-hornblende barometer (Anderson \& Smith 1995). The $\mathrm{Fe}_{\mathrm{t}} /\left(\mathrm{Fe}_{\mathrm{t}}+\mathrm{Mg}\right)$ ratio of amphibole is in the range of $0.65-0.45$ and $0.53-0.48$ for the Serra Negra and Serra Branca granites, respectively.

Schmidt (1992) proposed an Al-in-amphibole barometer, experimentally calibrated under water-saturated conditions at pressures of $2.5-13 \mathrm{kbar}, \mathrm{fO}_{2}<\mathrm{NNO}$ and temperatures of $700-655^{\circ} \mathrm{C}$ with a precision of $0.6 \mathrm{kbar}$ $[\mathrm{P}(0.6 \mathrm{kbar})=4.76 \mathrm{Al}-3.01]$. Anderson and Smith (1995), using experimental data at $\sim 675^{\circ} \mathrm{C}$ (Schmidt 1992) and at $\sim 760^{\circ} \mathrm{C}$ (Johnson \& Rutherford 1989), revised the calibration of Schmidt (1992) incorporating the effect of temperature, 
obtained by the geothermometer plagioclase - amphibole: $\mathrm{P}( \pm 0.6 \mathrm{kbar})=4.76 \mathrm{Al}-3.01-\left\{\left[\mathrm{T}\left({ }^{\circ} \mathrm{C}\right)-675\right] / 85\right\} \times\left\{0.53 \mathrm{Al}_{\text {total }}\right.$ $\left.+0.00529 \times\left[\mathrm{T}\left({ }^{\circ} \mathrm{C}\right)-675\right]\right\}$.

Using the Anderson and Smith (1995) geobarometer with crystallization temperatures obtained through the amphibole-plagioclase geothermometer, pressure in the 4.72-5.42 \pm 0.6 kbar range were obtained for the crystallization conditions of the Serra Negra granites, while the Serra Branca granites crystallized at higher crust under pressures of $2.71-2.84 \pm 0.6 \mathrm{kbar}$.

\section{Geothermometer amphibole - plagioclase}

The geothermometer amphibole - plagioclase can be used for granitic rocks when amphibole occurs in equilibrium with plagioclase. Blundy and Holland (1990), based on the reactions: edenite +4 quartz $\leftrightarrow$ tremolite + albite and pargasite +4 quatz $\leftrightarrow$ hornblende + albite, correlated the temperature with the $\mathrm{Al}^{\mathrm{IV}}$ contents in amphibole and albite molecule in plagioclase. The use of the amphibole - plagioclase geothermometer is conditioned to the following rules: the amphibole should have $\mathrm{Si}<7.8$ apfu (atom per formula unit) and the plagioclase composition with $\mathrm{An}<92 \%$. Both conditions are achieved by the Serra Negra and Serra Branca granites. The plagioclase - amphibole equilibrium temperatures, obtained through the Blundy and Holland (1990) geothermometer, were $666-670^{\circ} \mathrm{C}$ for the Serra Branca granite, and $711-751^{\circ} \mathrm{C}$ for the Serra Negra granite (Tab. 6).

\section{Zircon saturation geothermometer}

This geothermometer is based on the principle that $\mathrm{Zr}$ partition coefficients in crustal felsic magmas are a function of temperature (Watson 1979, Watson \& Harrison 1983, 1984). Watson and Harrison (1983) stablished an equation to define the zircon crystallization temperatures, using the zircon contents in the whole-rock composition. Zircon saturation thermometer (Watson \& Harrison 1983) defined temperatures within the $768-792^{\circ} \mathrm{C}$ range to the Serra Branca granites crystallization and $756-762^{\circ} \mathrm{C}$ to the Serra Negra granites crystallization (Tab. 6). The recorded temperatures are higher than those defined by the amphibole - plagioclase thermometer, which is expected, due the early crystallization of zircon, and are interpreted as the liquidus minimum temperature. On the other hand, the higher temperature can be caused by the presence of inherited zircon grains as have been reported from many plutons in the region.
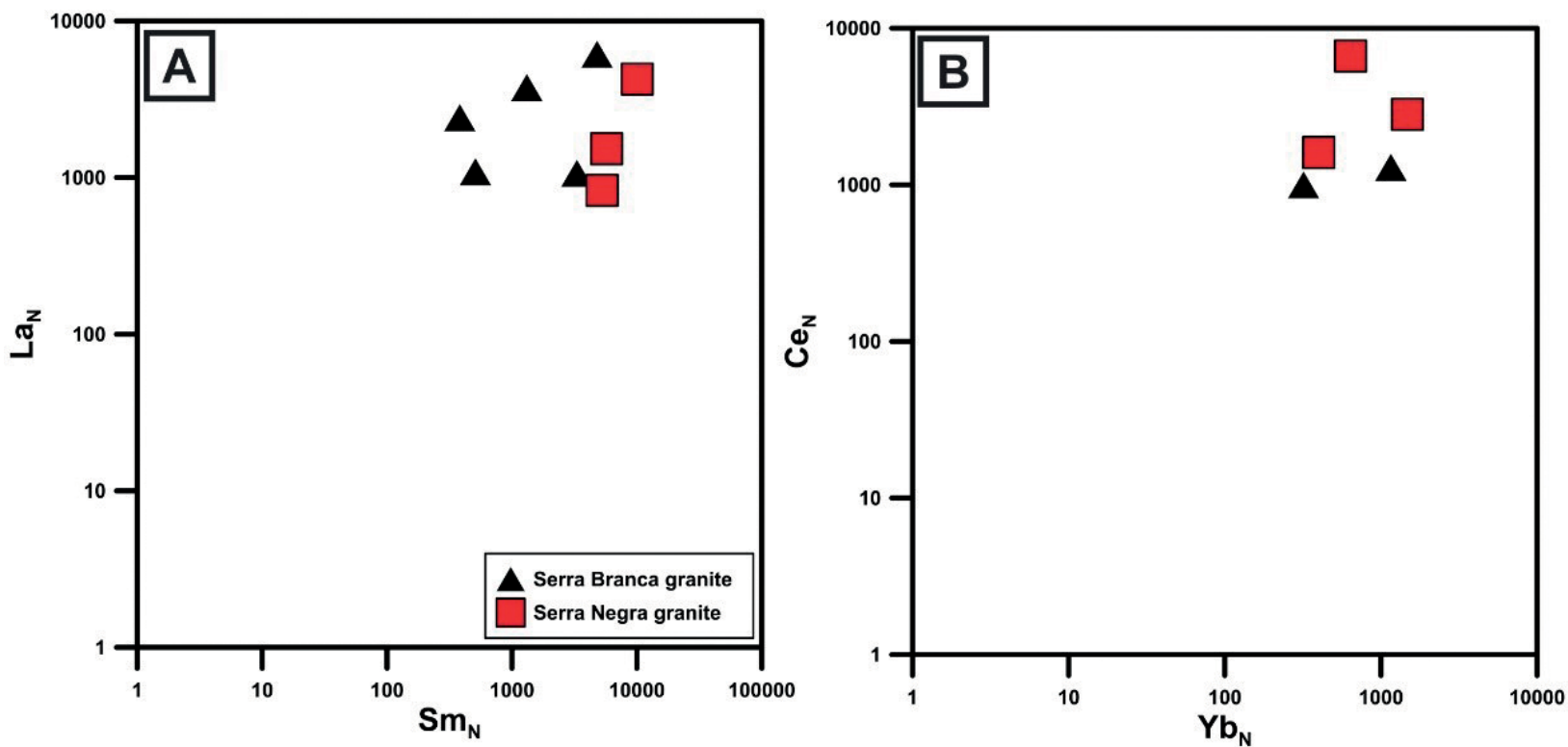

Figure 10. (A) Titanite crystals from the studied granites plotted on the $\mathrm{La}_{\mathrm{N}}$ versus $\mathrm{Sm}_{\mathrm{N}}$ diagram; (B) Titanite crystals from the studied granites plotted on the $\mathrm{Ce}_{\mathrm{N}}$ versus $\mathrm{Yb}_{\mathrm{N}}$

Table 6. Temperature and pressure data obtained from the amphibole-plagioclase geothermometer and zirconium saturation, and the total Al geobarometer in amphibole.

\begin{tabular}{|c|c|c|c|c|c|c|c|}
\hline Lithotypes & & Serra Br & granite & & & Negra gra & \\
\hline $\begin{array}{l}\mathrm{T}\left( \pm 75^{\circ} \mathrm{C}\right) \\
\text { amphibole-plagioclase } \\
\text { geothermometer }\end{array}$ & $670^{\circ} \mathrm{C}$ & $670^{\circ} \mathrm{C}$ & $670^{\circ} \mathrm{C}$ & $667^{\circ} \mathrm{C}$ & $751^{\circ} \mathrm{C}$ & $741^{\circ} \mathrm{C}$ & $711^{\circ} \mathrm{C}$ \\
\hline $\begin{array}{l}\mathrm{P}( \pm 0.6 \mathrm{kbar}) \\
\text { amphibole barometer }\end{array}$ & $2.73 \mathrm{kbar}$ & $2.80 \mathrm{kbar}$ & $2.68 \mathrm{kbar}$ & $2.71 \mathrm{kbar}$ & $5.42 \mathrm{kbar}$ & $5.09 \mathrm{kbar}$ & $4.72 \mathrm{kbar}$ \\
\hline $\begin{array}{l}\mathrm{T}^{\circ} \mathrm{C} \\
\mathrm{Zr} \text { saturation geothermometer }\end{array}$ & $793^{\circ} \mathrm{C}$ & $768^{\circ} \mathrm{C}$ & $776^{\circ} \mathrm{C}$ & & $763^{\circ} \mathrm{C}$ & $756^{\circ} \mathrm{C}$ & $773^{\circ} \mathrm{C}$ \\
\hline $\mathrm{LogfO}_{2}$ & -17.41 & -17.39 & -17.39 & -17.51 & -14.63 & -14.94 & -15.83 \\
\hline
\end{tabular}




\section{Oxygen fugacity}

Oxygen fugacity is a magmatic source dependent (Loiselle \& Wones 1979, Gill 1981, Wones 1989, Ishihara 1998), and it has an important influence on the liquidus temperature (Wones 1989) and therefor on, melt, mineral composition (Abbott \& Clarke 1979, Abott 1985), magmatic process control, crystallization sequence, and types of crystallized minerals (Botcharnikov et al. 2005, France et al. 2010). According to Wones (1989), the equilibrium assemblage hedenbergite + ilmenite + oxygen $\leftrightarrow$ titanite + magnetite + quartz is important in distinguishing relatively oxidized from relatively reduced granitic rocks. The equilibrium expression is expressed by log $\mathrm{fO}_{2}=-30930 / \mathrm{T}+14.98+0.142(\mathrm{P}-1) / 7$, where $\mathrm{T}$ is the temperature (in kelvins) and $\mathrm{P}$ is the pressure (in bars). Occurrences of hedenbergite-rich clinopyroxene and ilmenite in granitic plutons imply oxygen fugacities like those required for the stability of fayalite. When the assemblage titanite + magnetite + quartz occurs with clinopyroxene or amphibole with intermediate or higher $\mathrm{Mg} /(\mathrm{Mg}+\mathrm{Fe})$ ratios, a relatively high oxygen fugacity is implied.

The $\mathrm{fO}_{2}$ values for the Serra Branca granites crystallization are in the $10^{-17}$ order, while the Serra Negra $\mathrm{fO}_{2}$ values are in the order of $10^{-14}$ to $10^{-15}$. The data suggests that both granites crystallized under high $\mathrm{fO}_{2}$, above the hematite buffer (Fig. 11), confirming the results obtained by the chemistry of amphibole.

\section{U-Pb GEOCHRONOLOGICAL DATA}

Zircon grains from two granitoid samples (AJ-94 - Serra Negra Pluton; AMZ-115 - Serra Branca Pluton) were selected to define the crystallization ages of the studied plutons. The rocks were initially crushed and sieved, and the grain separation was done through conventional gravimetric and magnetic methods.

$\mathrm{U}-\mathrm{Pb}$ zircon analyses were carried out at the Geochronology Laboratory of the Universidade de Brasília using a ThermoFisher Neptune high-resolution multicollector ICP-MS coupled with a Nd: YAG UP213 New Wave laser ablation system, using the standard-sample bracketing method (Albarède et al. 2004). The GJ-1 standard zircon (Jackson et al. 2004)

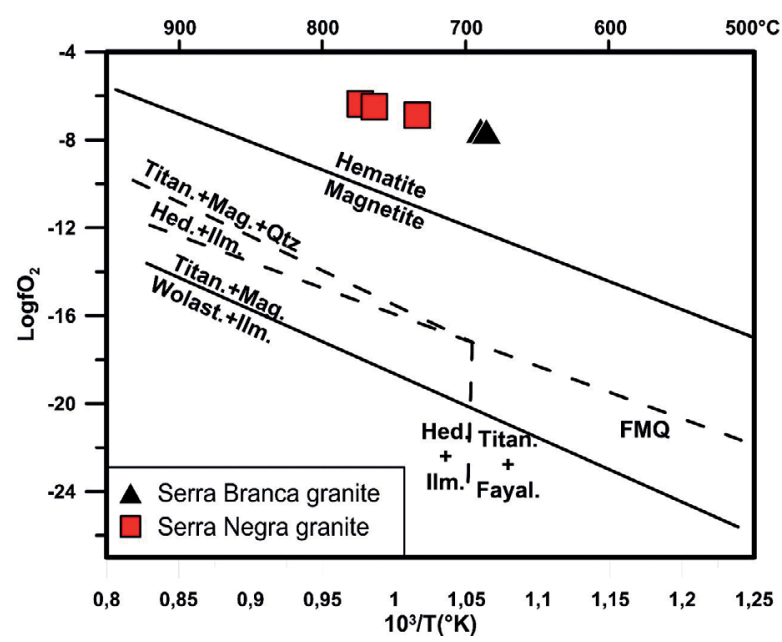

Figure 11. Oxygen fugacity of the studied granites obtained from the $\log \mathrm{fO}_{2}$ versus $10^{3} / \mathrm{T}\left({ }^{\circ} \mathrm{K}\right)$ diagram (Wones 1989). was used to quantify the amount of ICP-MS fractionation. The integration time was $1 \mathrm{~s}$, and the ablation time was $40 \mathrm{~s}$. A $25-\mu \mathrm{m}$ spot size was used, and the laser settings were $10 \mathrm{~Hz}$ and $2-3 \mathrm{~J} / \mathrm{cm}^{2} .{ }^{206} \mathrm{~Pb} /{ }^{207} \mathrm{~Pb}$ and ${ }^{206} \mathrm{~Pb} /{ }^{238} \mathrm{U}$ ratios were time corrected. Common ${ }^{204} \mathrm{~Pb}$ was monitored using the ${ }^{202} \mathrm{Hg}$ and $\left({ }^{204} \mathrm{Hg} /{ }^{204} \mathrm{~Pb}\right)$ masses. Common- $\mathrm{Pb}$ corrections were not done due to low signals for ${ }^{204} \mathrm{~Pb}(<30 \mathrm{cps})$ and high ${ }^{206} \mathrm{~Pb} /{ }^{204} \mathrm{~Pb}$ ratios. The zircon standard 91500 (Jackson et al. 2004) was analyzed as an external standard.

Age calculations were performed using in-house developed Excel worksheets. Backscattered images were used to investigate the internal structures of individual zircon crystals prior to each analysis, in order to define the better grains and spot locations. Discordant ages were defined by $\left(1-\left[{ }^{206} \mathrm{~Pb} /{ }^{238} \mathrm{U}\right.\right.$ age $/$ ${ }^{207} \mathrm{~Pb} /{ }^{206} \mathrm{~Pb}$ age $\left.]{ }^{*} 100\right)>10$.

\section{Sample AJ-94}

This sample is a biotite amphibole granite (632'52”S, $\left.38^{\circ} 17^{\prime} 35^{\prime \prime} \mathrm{W}\right)$. The zircon grains extracted from this granite are usually prismatic or square-like. Their lengths range from 50 to $150 \mu \mathrm{m}$ and aspect length/width ratios range from 2:1 to $1: 1$. Almost all grains show oscillatory magmatic zoning and fractures (Fig. 12A). They exhibit forms with dominant presence of $\{211\}$, which, according to Corfu et al. (2003), are typical zircon crystal shapes of aluminous to calc-alkaline rocks.

Thirty-six spots on thirty grains were analyzed. All of them have ${ }^{232} \mathrm{Th} /{ }^{238} \mathrm{U}$ ratios $>0.2$ which is typical of magmatic zircon (Williams \& Claesson 1987). Sixteen spots were discarded due to discordance $>10$, as also two analyzed spots due to high ${ }^{204} \mathrm{~Pb}$ contents and other nine due to high analytical errors. Nine concordant analyses (Tab. 7) were used to build up a Discordia (Fig. 12B), which defined a Concordia age of
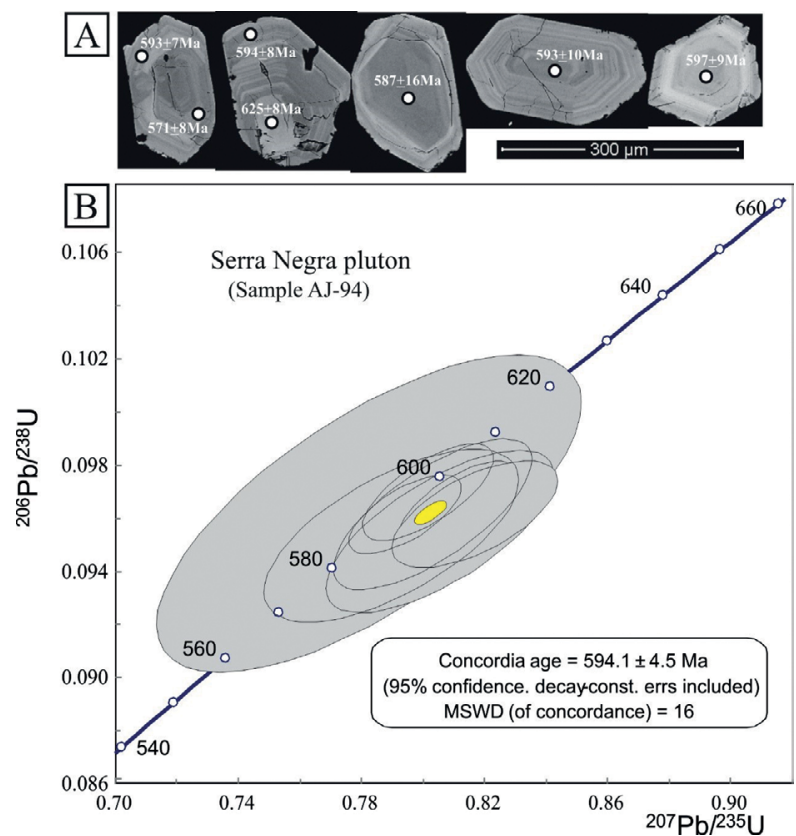

MSWD: Mean Square Weighted Deviation.

Figure 12. (A) Backscattered images of analyzed zircon grains of the Serra Negra granite and laser spot locations with their respectively ${ }^{206} \mathrm{~Pb} /{ }^{238} \mathrm{U}$ ages; (B) Concordia diagram for the Serra Negra granite. 
$594 \pm 4 \mathrm{Ma}$. This age is interpreted as the crystallization age of the Serra Negra granitoids. Cores and rims show similar ages and inherited cores and overgrowths were not recorded. The crystallization age defined to the Serra Negra granitoids is similar to those described in some high-K granitoids from the Transversal sub-province (Guimarães et al. 2004, Archanjo \& Fetter 2004, Archanjo et al. 2008, among others).

\section{Sample AMZ-115}

This sample comprises a biotite amphibole monzogranite collected far away from the pegmatite (6 32 '21.4”S, $\left.38^{\circ} 16^{\prime} 45^{\prime \prime} \mathrm{W}\right)$. The zircon grains are usually elongate, prismatic, with length ranging from 460 to $120 \mu \mathrm{m}$ and length/ width ratios from $4: 1$ to $2: 1$. Most of the grains show $\{100\}$ and $\{101\}$ forms, which are typical zircon grain shapes of dry alkali and tholeiitic igneous rocks (Corfu et al. 2003).

Thirty grains were analyzed totaling thirty-four spots. The analyzed zircon grains are euhedral to subhedral and show igneous zoning (Fig. 13A). Inherited cores (Fig. 13A and Tab. 8) show Paleoproterozoic ${ }^{207} \mathrm{~Pb} /{ }^{206} \mathrm{~Pb}$ ages (2199 to $2147 \mathrm{Ma}$ ) and high ${ }^{232} \mathrm{Th} /{ }^{238} \mathrm{U}$ ratios $(>2)$, reflecting an igneous source (Williams \& Claesson 1987). The recorded ages associated to the ${ }^{232} \mathrm{Th} /{ }^{238} \mathrm{U}$ ratios suggest that these cores were inherited from the orthogneisses country rocks (Caicó Complex). The zircons with inherited core have rims with igneous zoning, concordant Neoproterozoic ages and high ${ }^{232} \mathrm{Th} /{ }^{238} \mathrm{U}$ ratios (Fig. 13B). Seven spot analyses were discarded due to high analytical errors and/or high ${ }^{204} \mathrm{~Pb}$ content.

Table 7. Summary of laser ablation inductively coupled plasma mass spectrometry (LA-ICP-MS) data of zircons from rock sample AJ-94 of the Serra Negra granites.

\begin{tabular}{|c|c|c|c|c|c|c|c|c|c|c|c|c|c|c|}
\hline \multicolumn{7}{|c|}{ Isotopic rations } & \multicolumn{8}{|c|}{ Apparent ages } \\
\hline $\begin{array}{l}\text { Grain } \\
\text { spot }\end{array}$ & $\begin{array}{c}{ }^{207} \mathrm{~Pb} / \\
{ }^{206} \mathrm{~Pb}\end{array}$ & $\pm(1 \sigma)$ & $\begin{array}{c}{ }^{207} \mathbf{P b} / \\
{ }^{235} \mathbf{U}\end{array}$ & $\pm(1 \sigma)$ & $\begin{array}{c}{ }^{206} \mathbf{P b} / \\
{ }^{238} \mathrm{U}\end{array}$ & $\pm(1 \sigma)$ & $\begin{array}{c}{ }^{207} \mathrm{~Pb} / \\
{ }^{206} \mathrm{~Pb}\end{array}$ & $\pm(1 \sigma)$ & $\begin{array}{c}{ }^{207} \mathrm{~Pb} / \\
{ }^{235} \mathrm{U}\end{array}$ & $\pm(1 \sigma)$ & $\begin{array}{c}{ }^{206} \mathrm{~Pb} / \\
{ }^{238} \mathrm{U}\end{array}$ & $\pm(1 \sigma)$ & Rho & $\mathbf{T h} / \mathbf{U}$ \\
\hline ZR1N & 0.06072 & 0.48 & 0.800 & 0.94 & 0.0955 & 0.71 & 629 & 21 & 597 & 8 & 588 & 8 & 0.76 & 1.191 \\
\hline ZR6 & 0.06046 & 1.07 & 0.804 & 1.66 & 0.0964 & 1.20 & 620 & 46 & 599 & 15 & 593 & 14 & 0.73 & 0.534 \\
\hline ZR11B & 0.06087 & 0.54 & 0.810 & 0.96 & 0.0966 & 0.70 & 635 & 23 & 603 & 9 & 594 & 8 & 0.73 & 0.501 \\
\hline ZR12B & 0.05977 & 0.57 & 0.794 & 0.93 & 0.0963 & 0.63 & 595 & 25 & 593 & 8 & 593 & 7 & 0.68 & 0.511 \\
\hline ZR13 & 0.06115 & 1.29 & 0.806 & 1.88 & 0.0955 & 1.31 & 645 & 55 & 600 & 17 & 588 & 15 & 0.70 & 0.319 \\
\hline ZR19N & 0.06009 & 1.58 & 0.790 & 2.14 & 0.0953 & 1.39 & 607 & 67 & 591 & 19 & 587 & 16 & 0.65 & 0.832 \\
\hline ZR20 & 0.06147 & 0.99 & 0.817 & 1.36 & 0.0964 & 0.85 & 656 & 42 & 606 & 12 & 593 & 10 & 0.63 & 0.524 \\
\hline ZR27 & 0.05895 & 2.54 & 0.782 & 3.61 & 0.0962 & 2.53 & 565 & 109 & 587 & 32 & 592 & 29 & 0.70 & 0.633 \\
\hline ZR30 & 0.05990 & 0.67 & 0.801 & 1.08 & 0.0970 & 0.76 & 600 & 29 & 598 & 10 & 597 & 9 & 0.70 & 0.414 \\
\hline
\end{tabular}

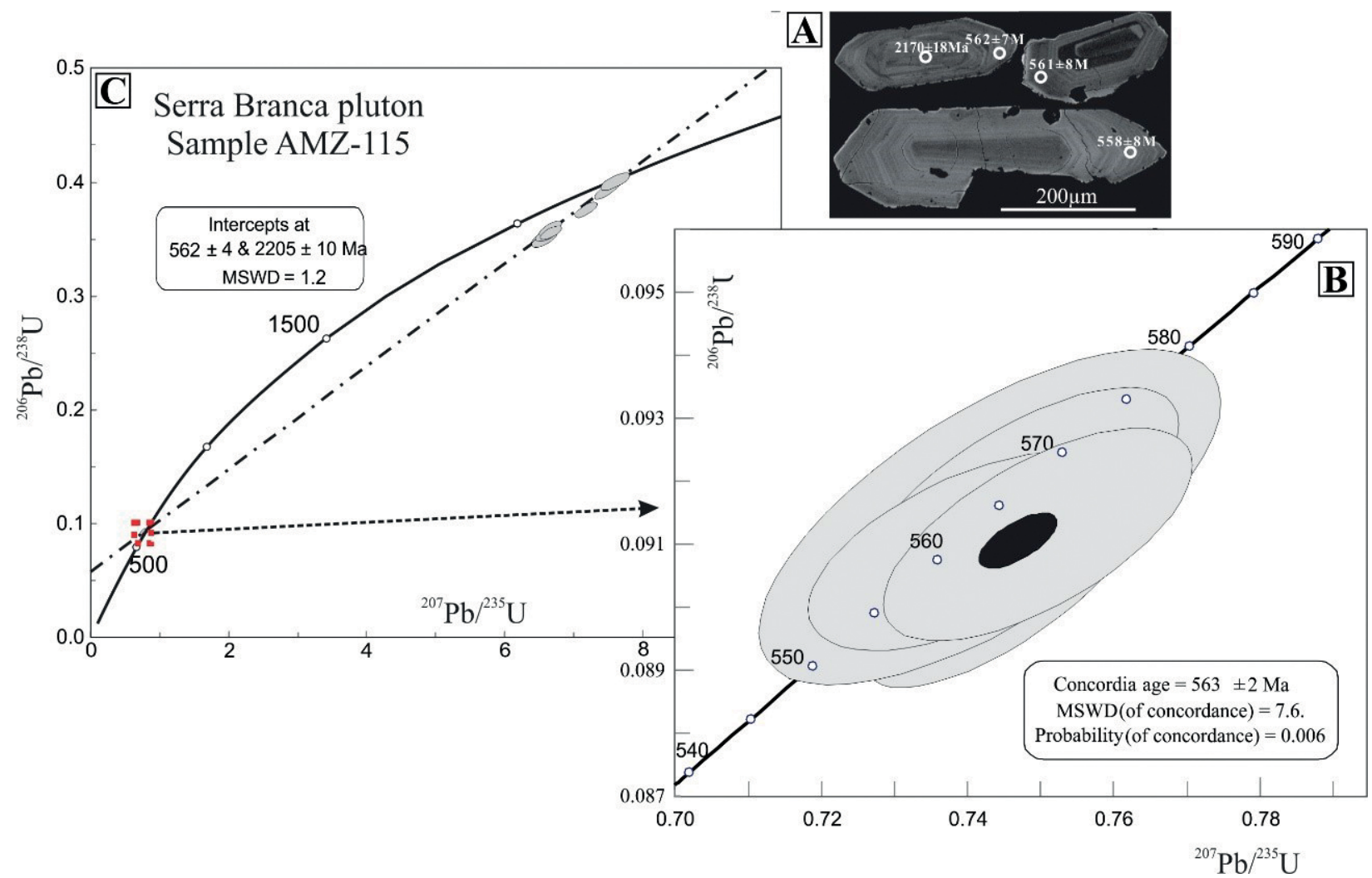

Figure 13. (A) Zircon SEM - CL pictures for analyzed zircon grains of the Serra Branca granite and laser spot locations with their respectively ages $\left({ }^{207} \mathrm{~Pb} /{ }^{206} \mathrm{~Pb}\right.$ ages - Paleoproterozoic, ${ }^{206} \mathrm{~Pb} /{ }^{238} \mathrm{U}$ ages - Neoproterozoic); (B) Zoom of the Neoproterozoic zircon cluster showed in (C); (C) Concordia diagram for all analyzed concordant zircon grains of the Serra Branca granite sample. 
The analyzed spots defined two clusters in the Concordia diagram (Fig. 13C). The Discordia defines an upper intercept age of $2205 \pm 10 \mathrm{Ma}$ and an age of $562 \pm 4 \mathrm{Ma}$ in the lower intercept. The Neoproterozoic analyzed spots have a Concordia age of $563 \pm 2 \mathrm{Ma}$, which is similar to that defined in the lower intercept, when all analyzed spots are considered. This age is interpreted as the crystallization age of the Serra Branca granitoids.

\section{GEOCHEMISTRY}

Nine samples were analyzed by ICP-AES for major elements and ICP-MS for trace elements, including samples of granites from the Serra Negra and Serra Branca plutons and three samples from the Serra Branca amazonite pegmatite. Whole-rock chemical composition of pegmatites is not common worldwide due to the difficulties in obtain representative sample from rocks with large crystals and heterogeneities such as pegmatites (London 2008). Data from NYF- type pegmatite are even more scarce (Ercit 2005). In order to achieve the best representative samples of the Serra Branca amazonite pegmatite, a transversal sampling including albite and amazonite zones was done. The pegmatite sampling comprised $300 \mathrm{~kg}$ of $3.4 \times$ $0.2 \times 0.3 \mathrm{~m}$ block. The sample was grinded and quarter, then milled down to 200 mesh and then subdivided in three samples for geochemical analyses. The results are shown in Table 9.

Table 8. Summary of laser ablation inductively coupled plasma mass spectrometry (LA-ICP-MS) data of zircons from rock sample AMZ-115 of the Serra Branca granites.

\begin{tabular}{|c|c|c|c|c|c|c|c|c|c|c|c|c|c|c|}
\hline \multicolumn{7}{|c|}{ Isotopic rations } & \multicolumn{8}{|c|}{ Apparent ages } \\
\hline $\begin{array}{l}\text { Grain } \\
\text { spot }\end{array}$ & $\begin{array}{l}{ }^{207} \mathrm{~Pb} / \\
{ }^{206} \mathrm{~Pb}\end{array}$ & $\pm(1 \sigma)$ & $\begin{array}{c}{ }^{207} \mathbf{P b} / \\
{ }^{235} \mathbf{U}\end{array}$ & $\pm(1 \sigma)$ & $\begin{array}{c}{ }^{206} \mathbf{P b} / \\
{ }^{238} \mathbf{U}\end{array}$ & $\pm(1 \sigma)$ & $\begin{array}{l}{ }^{207} \mathrm{~Pb} / \\
{ }^{206} \mathrm{~Pb}\end{array}$ & $\pm(1 \sigma)$ & $\begin{array}{c}{ }^{207} \mathbf{P b} / \\
{ }^{235} \mathbf{U}\end{array}$ & $\pm(1 \sigma)$ & $\begin{array}{c}{ }^{206} \mathrm{~Pb} / \\
{ }^{238} \mathrm{U}\end{array}$ & $\pm(1 \sigma)$ & Rho & Th/U \\
\hline ZR2N & 0.13452 & 0.50 & 6.517 & 0.89 & 0.3514 & 0.63 & 2,158 & 17 & 2,048 & 16 & 1,941 & 21 & 0.71 & 0.550 \\
\hline ZR3B $^{*}$ & 0.05972 & 0.63 & 0.745 & 1.07 & 0.0905 & 0.78 & 593 & 27 & 565 & 9 & 558 & 8 & 0.73 & 0.389 \\
\hline ZR4N & 0.13773 & 0.55 & 7.158 & 0.96 & 0.3769 & 0.69 & 2,199 & 19 & 2,131 & 17 & 2,062 & 24 & 0.72 & 0.286 \\
\hline ZR5N & 0.13459 & 0.75 & 6.595 & 1.09 & 0.3554 & 0.70 & 2,159 & 26 & 2,059 & 19 & 1,960 & 24 & 0.64 & 0.628 \\
\hline ZR5B* & 0.05903 & 0.90 & 0.740 & 1.21 & 0.0909 & 0.71 & 568 & 39 & 562 & 10 & 561 & 8 & 0.59 & 0.325 \\
\hline ZR10 & 0.06071 & 0.88 & 0.791 & 1.18 & 0.0945 & 0.68 & 629 & 38 & 592 & 11 & 582 & 8 & 0.58 & 0.334 \\
\hline ZR11 & 0.06023 & 0.79 & 0.777 & 1.28 & 0.0936 & 0.94 & 612 & 34 & 584 & 11 & 577 & 10 & 0.73 & 0.257 \\
\hline ZR12N & 0.13371 & 0.53 & 6.644 & 0.96 & 0.3604 & 0.71 & 2,147 & 19 & 2,065 & 17 & 1,984 & 24 & 0.74 & 0.551 \\
\hline ZR13 & 0.05839 & 2.10 & 0.745 & 2.81 & 0.0925 & 1.82 & 544 & 91 & 565 & 24 & 570 & 20 & 0.65 & 0.364 \\
\hline ZR17* & 0.05893 & 1.21 & 0.743 & 1.74 & 0.0915 & 1.19 & 564 & 52 & 564 & 15 & 564 & 13 & 0.69 & 0.355 \\
\hline ZR19N & 0.13711 & 0.65 & 7.588 & 1.10 & 0.4013 & 0.81 & 2,191 & 22 & 2,183 & 20 & 2,175 & 30 & 0.74 & 0.489 \\
\hline ZR20B & 0.06046 & 0.55 & 0.778 & 1.03 & 0.0933 & 0.79 & 620 & 24 & 584 & 9 & 575 & 9 & 0.76 & 0.405 \\
\hline ZR27N & 0.13734 & 0.45 & 7.474 & 1.01 & 0.3947 & 0.82 & 2,194 & 15 & 2,170 & 18 & 2,144 & 30 & 0.82 & 0.683 \\
\hline ZR27B* & 0.05975 & 0.57 & 0.751 & 0.92 & 0.0911 & 0.61 & 595 & 25 & 569 & 8 & 562 & 7 & 0.67 & 0.573 \\
\hline ZR28 & 0.13513 & 0.55 & 6.643 & 0.93 & 0.3565 & 0.65 & 2,166 & 19 & 2,065 & 16 & 1,966 & 22 & 0.70 & 0.339 \\
\hline ZR29* & 0.05962 & 0.79 & 0.750 & 1.15 & 0.0912 & 0.75 & 590 & 34 & 568 & 10 & 563 & 8 & 0.65 & 0.286 \\
\hline ZR30N & 0.13563 & 0.76 & 6.545 & 1.13 & 0.3500 & 0.76 & 2,172 & 26 & 2,052 & 20 & 1,934 & 25 & 0.67 & 0.357 \\
\hline ZR30B* & 0.05910 & 0.80 & 0.747 & 1.21 & 0.0916 & 0.83 & 571 & 35 & 566 & 10 & 565 & 9 & 0.69 & 0.469 \\
\hline
\end{tabular}

*Zircons used to calculate the Concordia age diagram.

Table 9. Whole-rock chemical data performed by inductively coupled plasma mass spectrometry (ICP-MS) in the Serra Branca.

\begin{tabular}{|c|c|c|c|c|c|c|c|c|c|}
\hline \multirow{2}{*}{$\begin{array}{l}\text { Lithotypes } \\
\mathrm{SiO}_{2} \text { (wt.\%) }\end{array}$} & \multicolumn{3}{|c|}{ Serra Negra granite } & \multicolumn{3}{|c|}{ Serra Branca granite } & \multicolumn{3}{|c|}{ Serra Branca amazonite pegmatite } \\
\hline & 66.3 & 73.47 & 67.98 & 68.34 & 61.06 & 66.73 & 72.56 & 72.47 & 72.21 \\
\hline $\mathrm{Al}_{2} \mathrm{O}_{3}$ & 16.56 & 13.67 & 15.49 & 16.06 & 16 & 18.18 & 14.88 & 14.87 & 15.01 \\
\hline $\mathrm{Fe}_{2} \mathrm{O}_{3}$ & 2.19 & 1.87 & 2.28 & 2.17 & 4.8 & 2.02 & 0.29 & 0.28 & 0.28 \\
\hline $\mathrm{MgO}$ & 0.37 & 0.68 & 1.26 & 0.39 & 1.72 & 0.57 & 0.04 & 0.02 & 0.03 \\
\hline $\mathrm{CaO}$ & 2.01 & 1.65 & 1.94 & 1.26 & 2.93 & 1.45 & 0.04 & 0.04 & 0.04 \\
\hline $\mathrm{Na}_{2} \mathrm{O}$ & 3.69 & 4.91 & 4.53 & 5.07 & 4.71 & 8.74 & 3.31 & 3.42 & 3.4 \\
\hline $\mathrm{K}_{2} \mathrm{O}$ & 7.64 & 2.8 & 5.22 & 5.4 & 6.86 & 1.08 & 8.36 & 8.26 & 8.31 \\
\hline $\mathrm{TiO}_{2}$ & 0.19 & 0.15 & 0.26 & 0.2 & 0.43 & 0.23 & 0.02 & 0.01 & 0.01 \\
\hline $\mathrm{P}_{2} \mathrm{O}_{5}$ & 0.06 & 0.08 & 0.15 & 0.09 & 0.34 & 0.07 & $<0.01$ & $<0.01$ & $<0.01$ \\
\hline $\mathrm{MnO}$ & 0.07 & 0.03 & 0.04 & 0.04 & 0.09 & 0.23 & 0.02 & 0.02 & 0.02 \\
\hline $\mathrm{F}$ & 0.02 & 0.05 & 0.06 & 0.06 & 0.07 & 0.19 & 0.03 & 0.02 & 0.02 \\
\hline $\mathrm{Ba}(\mathrm{ppm})$ & 2,411 & 900 & 2,206 & 2,009 & 2,568 & 75 & 415 & 400 & 407 \\
\hline $\mathrm{Be}$ & 1 & 8 & 2 & 9 & 7 & 34 & 50 & 42 & 40 \\
\hline Cs & 12.7 & 2.8 & 3 & 4.1 & 5.6 & 50.6 & 131.8 & 129.4 & 129.5 \\
\hline $\mathrm{Ga}$ & 17.5 & 17.9 & 18.4 & 20.4 & 19.7 & 38.1 & 52 & 53.3 & 50.4 \\
\hline Hf & 3.3 & 3.2 & 3.8 & 4.5 & 3.1 & 4.9 & 2.4 & 14.5 & 2.3 \\
\hline
\end{tabular}


Table 9. Continuation.

\begin{tabular}{l|ccc|ccc|ccc}
\hline Lithotypes & \multicolumn{3}{|c|}{ Serra Negra granite } & \multicolumn{3}{c|}{ Serra Branca granite } & \multicolumn{3}{c}{ Serra Branca amazonite pegmatite } \\
\hline $\mathrm{Nb}$ & 6.6 & 5.7 & 8.5 & 10.4 & 7.3 & 50.5 & 56.5 & 74.5 & 34 \\
$\mathrm{Rb}$ & 211 & 97 & 153 & 216 & 200 & 271 & 3,004 & 2,994 & 3016 \\
$\mathrm{Sr}$ & 913 & 1096 & 1,280 & 1,429 & 1,420 & 508 & 217 & 210 & 213 \\
$\mathrm{Ta}$ & 0.5 & 0.4 & 0.7 & 0.7 & 0.5 & 1.7 & 8.2 & 11.5 & 5.6 \\
$\mathrm{Zr}$ & 113 & 104 & 127 & 160 & 121 & 132 & 17.5 & 117.8 & 12.1 \\
$\mathrm{Y}$ & 8.6 & 6 & 8.3 & 21.5 & 17.8 & 7.2 & 7.1 & 7.3 & 5.7 \\
$\mathrm{Cr}$ & 68 & 89 & 103 & 130 & 68 & 109 & 82 & 82 & 89 \\
$\mathrm{Cu}$ & 2.1 & 0.9 & 0.7 & 8.1 & 40.8 & 3 & 13.5 & 13 & 13.1 \\
$\mathrm{~Pb}$ & 25.9 & 5.6 & 4.1 & 7.2 & 4.6 & 38.4 & 193 & 189.7 & 185.6 \\
$\mathrm{Zn}$ & 22 & 16 & 17 & 27 & 25 & 166 & 23 & 24 & 23 \\
$\mathrm{La}$ & 18.8 & 14.9 & 23.2 & 79 & 48.6 & 9.1 & 1 & 0.9 & 0.6 \\
$\mathrm{Ce}$ & 27.5 & 24.5 & 42.8 & 81.7 & 80.8 & 29.1 & 1.5 & 2.1 & 1.4 \\
$\mathrm{Pr}$ & 3.38 & 2.58 & 4.72 & 11.7 & 8.9 & 1.8 & 0.23 & 0.31 & 0.17 \\
$\mathrm{Nd}$ & 11.8 & 8.8 & 16.7 & 40.3 & 33.1 & 5.8 & 0.8 & 1.1 & 0.8 \\
$\mathrm{Sm}$ & 2.01 & 1.76 & 3.08 & 6.41 & 5.76 & 1.01 & 0.32 & 0.39 & 0.29 \\
$\mathrm{Eu}$ & 0.83 & 0.48 & 0.86 & 1.92 & 1.72 & 0.29 & 0.1 & 0.1 & 0.09 \\
$\mathrm{Gd}$ & 1.83 & 1.25 & 2.28 & 4.86 & 4.57 & 0.95 & 0.42 & 0.48 & 0.35 \\
$\mathrm{~Tb}$ & 0.25 & 0.19 & 0.3 & 0.66 & 0.59 & 0.13 & 0.09 & 0.08 & 0.07 \\
$\mathrm{Dy}$ & 1.44 & 0.97 & 1.61 & 3.41 & 3.12 & 0.72 & 0.57 & 0.62 & 0.45 \\
$\mathrm{Ho}$ & 0.3 & 0.19 & 0.34 & 0.66 & 0.6 & 0.2 & 0.12 & 0.13 & 0.1 \\
$\mathrm{Er}$ & 0.94 & 0.54 & 0.78 & 1.65 & 1.65 & 0.64 & 0.46 & 0.55 & 0.33 \\
$\mathrm{Tm}$ & 0.14 & 0.08 & 0.12 & 0.26 & 0.23 & 0.11 & 0.08 & 0.12 & 0.07 \\
$\mathrm{Yb}$ & 0.93 & 0.56 & 0.78 & 1.55 & 1.46 & 0.95 & 0.8 & 1.21 & 0.54 \\
$\mathrm{Lu}$ & 0.13 & 0.1 & 0.12 & 0.2 & 0.22 & 0.19 & 0.13 & 0.23 & 0.11 \\
\hline
\end{tabular}

\section{The Serra Negra and Serra Branca granites and the Serra Branca amazonite pegmatite}

The granitoids from the Serra Negra Pluton show higher $\mathrm{SiO}_{2}$ contents $(66-73 \mathrm{wt} . \%)$ compared to those of the Serra Branca pluton (61 - 68wt.\%). Granitoids from both plutons show high total alkalis $\left(\mathrm{K}_{2} \mathrm{O}+\mathrm{Na}_{2} \mathrm{O}\right)$ contents and $\mathrm{K}_{2} \mathrm{O} / \mathrm{Na}_{2} \mathrm{O}$ ratios $>1$. According to the Shand's index the granitoids of the Serra Negra Pluton are metaluminous while those from Serra Branca range from metaluminous to slightly peraluminous (Fig. 14A). The Alumina Saturation Index $\left(\mathrm{ASI}=\mathrm{Al}_{2} \mathrm{O}_{3} /(\mathrm{CaO}\right.$ $\left.+\mathrm{Na}_{2} \mathrm{O}+\mathrm{K}_{2} \mathrm{O}\right)$ of the Serra Negra and Serra Branca granites varies from 1.2 to 1.4 and from 1.1 to 1.3 , respectively.

The Serra Branca granitoids are alkaline while the Serra Negra granitoids plot in the calc-alkaline to alkaline (Fig. 14B) in the $\mathrm{MALI}\left(\mathrm{NaO}_{2}+\mathrm{K}_{2} \mathrm{O}-\mathrm{CaO}\right.$ ) versus $\mathrm{SiO}_{2}$ diagram (Frost et al. 2001). The Serra Branca granitoids show Fe\# $\left[\mathrm{FeO}_{\mathrm{t}} /\left(\mathrm{FeO}_{\mathrm{t}}+\right.\right.$ $\mathrm{MgO})$ ] ranging from 0.85 to 0.74 , and the Serra Negra granitoids show 0.86 to 0.64 values, both plotting in the magnesian field, except for two samples which fall in the ferroan field, in the $\mathrm{SiO}_{2}$ versus $\left(\mathrm{FeO}_{\mathrm{t}} /\left(\mathrm{FeO}_{\mathrm{t}}+\mathrm{MgO}\right)\right.$ diagram (Fig. 14C), with classification after Frost et al. (2001). The magnesian granitoids are associated to crystallization under high $\mathrm{fO}_{2}$ condition while ferroan granitoids are crystallized under low $\mathrm{fO}_{2}$ conditions.

The REE patterns of the Serra Negra granites, normalized to chondrite values of Nakamura (1974), are characterized by $(\mathrm{Ce} / \mathrm{Yb})_{\mathrm{N}}$ ratios varying from 7.52 to 13.96 and absence of Eu anomalies (Fig. 15A). These patterns are similar to those recorded in the tonalitic orthogneisses of the Caicó Complex (Fig. 15A), except by higher contents of total REE in the Caicó tonalitic orthogneisses, which can be explained by amphibole in the melting residue. The Serra Branca granites show REE patterns like those of the Serra Negra granites. One sample classified as medium to fine grained leucogranite, showed lower LREE and medium rare earth elements (MREE) contents compared to the two other samples. The REE patterns of the Serra Branca granites are like those of the Serra Negra granites, with similar $(\mathrm{Ce} / \mathrm{Yb})_{\mathrm{N}}$ ratios (7.52 to 13.96), but have higher total REE concentration.

The Serra Branca amazonite pegmatite shows very low LREE contents, heavy rare earth elements (HREE) similar to those recorded in the Serra Negra and Serra Branca granitoids, and patterns characterized by $\mathrm{Ce} / \mathrm{Yb}$ ratios $<1$. The Serra Negra REE patterns are characterized by $(\mathrm{Ce} / \mathrm{Yb})$ ${ }_{N}$ ratios ranging from 7.52 to 13.96 , with absent or positive $\mathrm{Eu}$ anomalies (Fig. 15A).

The spidergrams for the analyzed samples from the Serra Negra e Serra Branca granitoids are similar in shape, except by the higher LREE, K, Sr, P, Ti and Y contents in the Serra Branca granitoids patterns. On the other hand, the spidergram from the medium to fine grained leucogranite facies of the Serra Branca pluton is distinct from others Serra Branca and Serra Negra granitoids. This leucogranite facies is characterized by higher $\mathrm{Cs}, \mathrm{Rb}, \mathrm{Pb}, \mathrm{Nb}$, Ta, and lower $\mathrm{Ba}, \mathrm{K}, \mathrm{Sr}, \mathrm{P}$ and LREE, being similar in shape to those recorded in the Serra Branca amazonite pegmatite (Fig. 15B).

In the tectonic setting discriminant diagrams of Pearce et al. (1984), the Serra Negra granites fall in the volcanic arc (VAG) and syn-collisional (syn-COLG) fields, and the Serra Branca granites fall in the VAG, syn-COLG and within plate 
(WPG) fields. In the Pearce (1996) diagram, the Serra Branca granites fall within the Post-Orogenic granites (POG) field, while the Serra Negra granites fall in the VAG and syn-COLG fields. According to Pearce et al. (1990) and Pearce (1996), the trace elements composition of a melt generated by lithosphere zone undergoing melting can show either volcanic arc or within plate character, depending on the previous geotectonic history. Besides that, crustal sources (lower, upper and bulk) have often a volcanic arc character (Fig. 14D). On the other hand, $\mathrm{Y}$ behaves as a compatible element during melting or fractional crystallization if there is a melt residue or crystallization assemblage involving amphibole and/or garnet. Thus, these
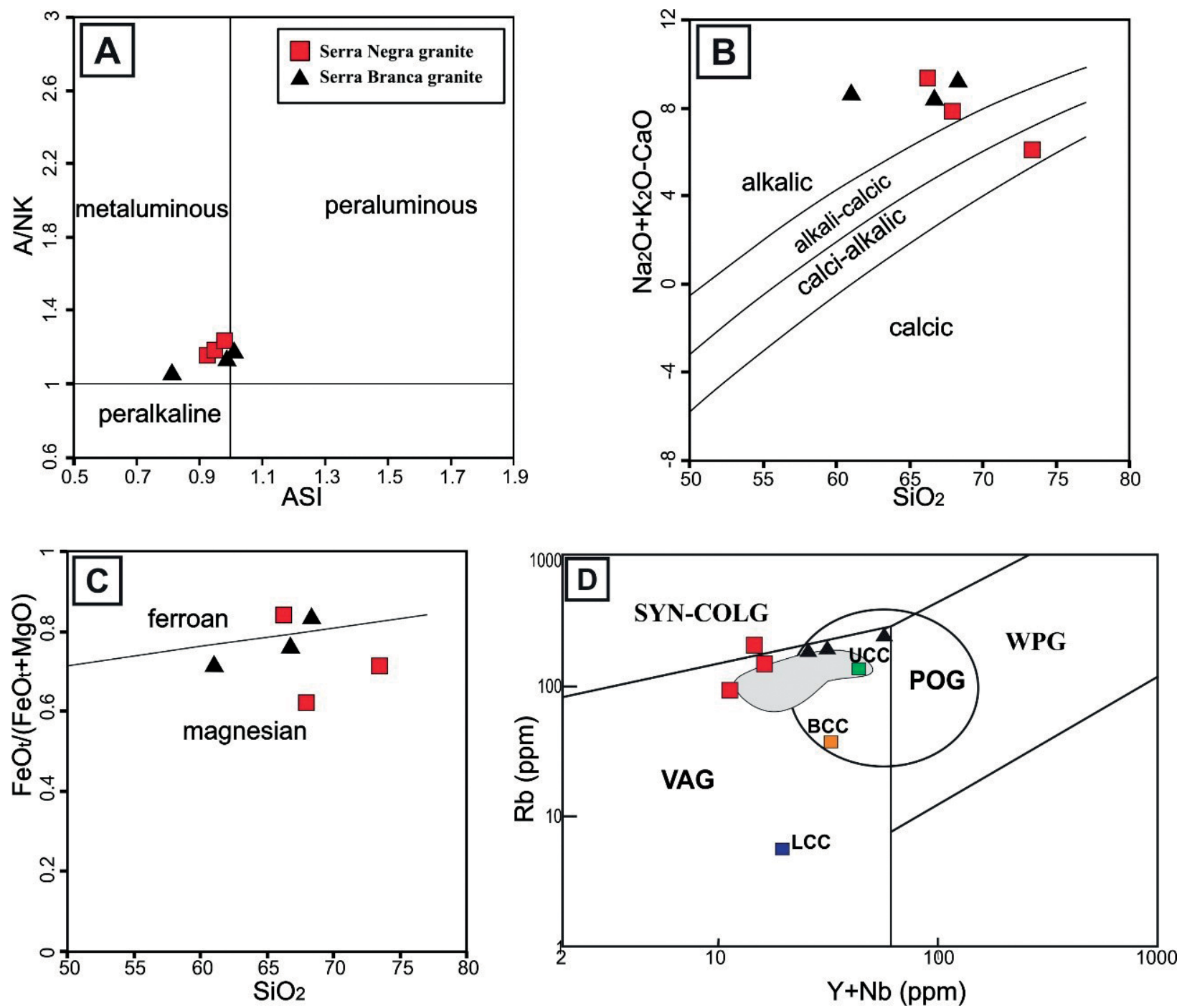

VAG: volcanic arc granite; POG: Post-Orogenic granites; WPG: within plate granite; SYN-COLG: syn-collisional.

Figure 14. (A) Studied rocks classification according to Shand's index (1943); (B) $\mathrm{SiO}_{2}$ versus $\mathrm{MALI}\left(\mathrm{NaO}+\mathrm{K}_{2} \mathrm{O}-\mathrm{CaO}\right)$ diagram (Frost et al. 2001); (C) Studied granites plotted on $\mathrm{FeO}_{\mathrm{t}} /\left(\mathrm{FeO}_{\mathrm{t}}+\mathrm{MgO}\right.$ ) versus $\mathrm{SiO}_{2}$ diagram (Frost et al. 2001); (D) Tectonic discrimination diagram of $\mathrm{Rb}$ vs. ( $\mathrm{Y}+\mathrm{Nb}$ ) (Pearce et al. 1984) for the studied granites (UCC: Composition of Upper Continental Crust, BCC: Composition of Bulk Continental Crust, LCC: Composition of Lower Continental Crust from Pearce (1996). The gray area represents the composition from the rocks of the Caicó complex).
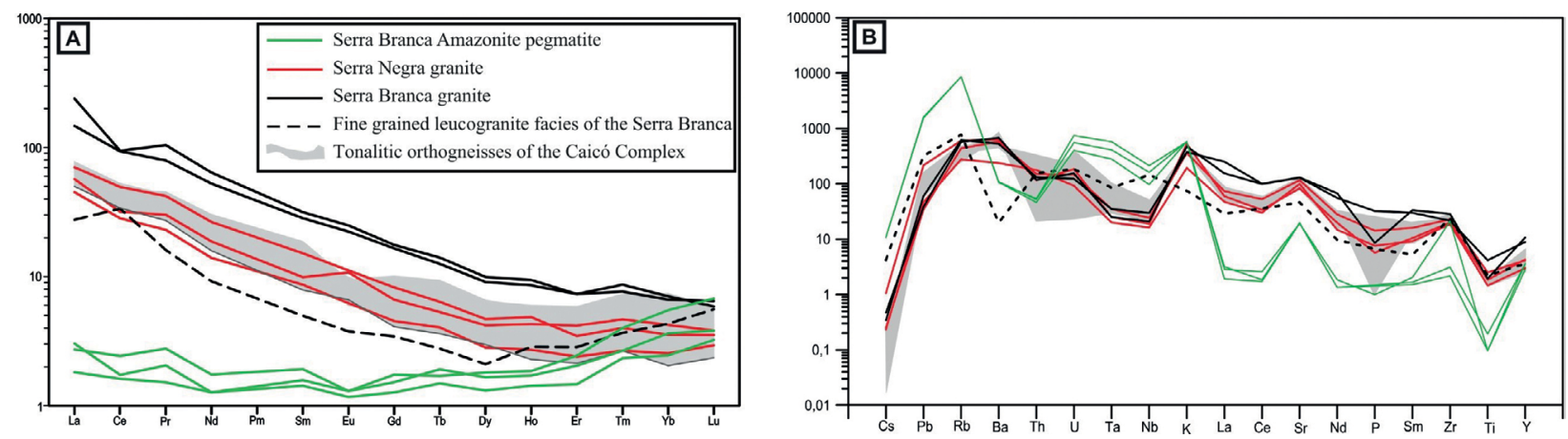

Figure 15. Selected chemical data of Serra Branca and Serra Negra granites, Serra Branca amazonite pegmatite and the Caicó Complex tonalitic orthogneiss: (A) REE pattern normalized by chondrite (Nakamura 1974); (B) Spidergram normalized to the chondrite (Sun 1980). 
discriminant diagrams reflect the source composition and the processes involved during the magma evolution, rather than the setting in which the melt was generated and crystallized.

\section{DISCUSSION}

The field relationships and geochronological data show that the Serra Branca pluton is younger than the Serra Negra Pluton, and the amazonite pegmatite was intruded only into the Serra Branca granites. The Serra Negra pluton shows elongated shape, NE-SW-trending, magmatic foliation and S-C foliation, with $\mathrm{C}$ foliation plane aligned parallel to the NE-SW trending branch of the Lastro and Vieirópolis dextral shear zones, suggesting that the Serra Negra granitoids were emplaced syn- to late-transcurrence, $594 \mathrm{Ma}$ ago, coeval with high-K granitoids described in the Transversal subprovince. The crystallization age $(563 \pm 2 \mathrm{Ma})$, defined for the granitoids of the Serra Branca Pluton, confirms the field relationships and dates the end of the transcurrent regime in the area.

The Serra Negra and Serra Branca granitoids show high $\mathrm{SiO}_{2}$ and $\mathrm{Al}_{2} \mathrm{O}_{3}$ contents, and low compatible elements $(\mathrm{MgO}$, $\mathrm{Cr}, \mathrm{Ni}$ ) contents, suggesting that their magma sources were crustal. The Serra Negra granitoids show trace element composition like those of the Caicó tonalitic orthogneisses (Fig. 15B), except by slightly higher Th and U contents, suggesting that the Serra Negra granitoids magma was generated by partial melting of a source geochemically similar to the Caicó tonalitic orthogneisses. A large percentage of melting from a source like the Caicó complex may explain the similarities between the trace elements composition of the Serra Negra granites and the Caicó orthogneisses and the absence of inherited zircon grains. The VAG signature of the Serra Negra granites is also an effect of their derivation from the Caicó orthogneisses, as shown in the $\mathrm{Rb}$ versus $(\mathrm{Y}+\mathrm{Nb})$ discriminant tectonic setting diagram (Pearce 1996), where the Caicó orthogneisses have a VAG signature (Fig. 14D). The detailed geochemical data presented by Souza et al. (2007) also shows that the Caicó tonalitic orthogneisses have a subduction-related signature. The presence of diorite enclaves hosted by the Serra Negra granites suggests that the necessary heating to promote the orthogneisses melting may have the influence of mafic magmas from the lithospheric mantle, ascending through the shear zones. However, isotopic data are necessary to confirm this hypothesis. The crystallization of the Serra Negra granitoids occurred at the medium crust ( 12 to $15 \mathrm{~km}$ ) under high $\mathrm{fO}_{2}$.

The Serra Branca granites are isotropic and post-transcurrence or post orogenic according to Pearce (1996) discriminant tectonic setting (Fig. 14D). The coarse-grained facies of the Serra Branca pluton are geochemically similar to the Serra Negra granitoids and Caicó orthogneisses, except by higher $\mathrm{Na}_{2} \mathrm{O}$, LREE, $\mathrm{P}$ and Ti contents, which suggests that the Serra Negra and Serra Branca granites share similar sources i.e., the Caicó orthogneisses. However, the trace element composition of the most differentiate facies (medium grained leucogranites) of the Serra Branca pluton is distinct from the coarse-grained facies by having higher incompatible element $(\mathrm{F}, \mathrm{Pb}, \mathrm{Rb}, \mathrm{Cs}$, $\mathrm{Nb}$ and $\mathrm{Ta}$ ) contents and lower $\mathrm{Ba}, \mathrm{Sr}, \mathrm{Y}$ and LREE contents, resembling in shape the trace element patterns of the Serra Branca amazonite pegmatite. During low degree of crustal melting at low-T conditions, or during fractional crystallization, $\mathrm{Pb}$ becomes strongly enriched in the melt relative to $\mathrm{Ba}$ and also relative to its source rock contents, because $\mathrm{Pb}$ is a more incompatible element. On the other hand, anatexis at high-T condition and large degree of partial melting produce melts less enriched in $\mathrm{Pb}$ and less depleted in $\mathrm{Ba}$ or even enriched relative to source rock (Finger \& Schiller 2012).

The incompatible $\mathrm{Pb}$ behavior, associated to K-feldspar and/or plagioclase fractional crystallization, and low-T crystallization temperature of the Serra Branca granites explain the high $\mathrm{Pb}$ and lower $\mathrm{Ba}$ contents in the Serra Branca amazonite pegmatite. According to Martin (2004), efficient fractionation leads to NYF-type pegmatites, with peralkaline or metaluminous signature. Mildly peraluminous character can be developed in epizonal plutons due to alkali loss during degassing. The Serra Branca granites crystallized at depth between 7.8 and $9.5 \mathrm{~km}$, under high $\mathrm{fO}_{2}$ conditions, and are metaluminous to slightly peraluminous.

The evolution of the Serra Branca granites magma involved fractional crystallization of $\pm \mathrm{K}$-feldspars, titanite, apatite and allanite (Fig. 16), leading to a melt enriched in incompatible elements ( $\mathrm{Cs}, \mathrm{Pb}, \mathrm{Rb}, \mathrm{U}, \mathrm{Ta}, \mathrm{Nb})$ that crystallized as the leucogranite, and a residual melt even enriched in $\mathrm{Pb}$ and $\mathrm{Rb}$, and LREE depleted. The melt continues fractionating apatite, titanite and allanite, resulting in a volatile rich product that finally crystallized as the amazonite pegmatite (Fig. 16). These variations, associated to the epizonal character of the Serra Branca pluton, provide evidence that the Serra Branca amazonite pegmatite resulted from extreme fractional crystallization of the Serra Branca granitic magma, which was generated by low degree of partial melting of a source similar to the Caicó orthogneisses, under high $\mathrm{fO}_{2}$ condition and relatively low $\mathrm{T}$ conditions. The origin of the Serra Branca granitic magma by partial melting of orthogneisses of the Caicó Complex is supported by the presence of inherited Paleoproterozoic zircon cores in the Serra Branca granites (Fig. 13). The absence of inherited zircon grains in the Serra Negra granites may be explained by higher magma temperatures.

\section{The Serra Branca amazonite pegmatite and its similarities with pegmatites worldwide}

The classification of granitic pegmatites proposed by Černý and Ercit (2005) is the most accepted worldwide. This classification deals with geological location and divided the granitic pegmatites into five classes (abyssal, muscovite, muscovite - rare-element, rare-element and miarolitic), with most of them subdivided into subclasses taking under consideration geochemical and geological characteristics. This classification also divided the pegmatites of igneous sources into three families:

- NYF family with progressive accumulation of $\mathrm{Nb}, \mathrm{Y}$ and $\mathrm{F}$ (besides Be, REE, Sc, Ti, Zr, Th and U), fractionated from subaluminous to metaluminous A- and I-type granites with crust or mantle contributions; 
- LCT family with high Li, Cs and Ta (besides Rb, Be, Sn, $\mathrm{B}, \mathrm{P}$ and F) contents, derived mainly from S-type granites, less commonly from I-type granites;

- $\operatorname{mixed}$ NYF + LCT.

The evidences for the Serra Branca amazonite pegmatite to be a NYF-type (Černý \& Ercit 2005) are:

- lack of Al- and Li-rich mineral phases, which are typical in the mineral assemblage of LCT-type pegmatite, occurrence of pyrochlore, rutile and ilmenite (high field strength elements-rich mineral phases) and biotite which are typical mineral phases of NYF-type pegmatites (Wise 2017);

- high $\mathrm{Nb}, \mathrm{Y}, \mathrm{F}, \mathrm{Ta}, \mathrm{Rb}$ and $\mathrm{Pb}$ contents;

- amazonite megracrysts mineralization, which, according to Martin et al. (2008), is a rare pegmatite mineralization in a global level, and its occurrence is restrict to NYF-type pegmatite.

Wise (1999) proposed a classification of the NYF pegmatites, based on 40 occurrences of post-tectonic to anorogenic plutons emplaced at shallow levels into non-compressional environment. He divided the NYF pegmatites into three groups, based on the alumina saturation of the parental granite, as peralkaline, metaluminous and peraluminous. Each group was subdivided using characteristic mineralogical and geochemical features. The metaluminous group, as the case of Serra Branca amazonite pegmatite, was subdivided in three subtypes:

- allanite subtype enriched in LREE $( \pm \mathrm{Ti}, \mathrm{Zr}, \mathrm{F})$;

- euxenite subtype characterized by $\mathrm{Nb}>\mathrm{Ta}, \mathrm{Ti}, \mathrm{Zr}, \mathrm{Y}, \mathrm{P}$, LREE to HREE minerals;

- the gadolinite subtype, with $\mathrm{Be}, \mathrm{Y}+\mathrm{HREE}, \mathrm{Nb}>\mathrm{Ta}$, Ti, $\mathrm{Zr}$, P, and F.

The Serra Branca amazonite pegmatite have moderate $\mathrm{Be}$ (40 to $50 \mathrm{ppm}$ ) contents, Be-bearing mineral phases (helvine and phenakite) within the amazonite zone and HREE contents higher than LREE contents, which characterizes the studied pegmatite as a gadolinite subtype.

According to Černý and Ercit (2005), the NYF-type pegmatites are associated to metaluminous I- (syn-, tardi- to post-orogenic, NYF-I) and A-type granitoids (anorogenic, NYF-A). The Serra Branca amazonite pegmatite are likely from NYF-I subtype, due its derivation from the I-type Serra Branca granites, originated from partial melting of orthogneisses of the Caicó Complex.

Whole-rock geochemical data for NYF pegmatites is rare in the literature. However, some data, available for NYF-type pegmatites without amazonite mineralization from the Hearne Province in northern Saskatchewan, Canada (McKeough et al. 2013), and three others, one amazonite pegmatite and two without amazonite mineralization, from Evje-Iveland, Norway
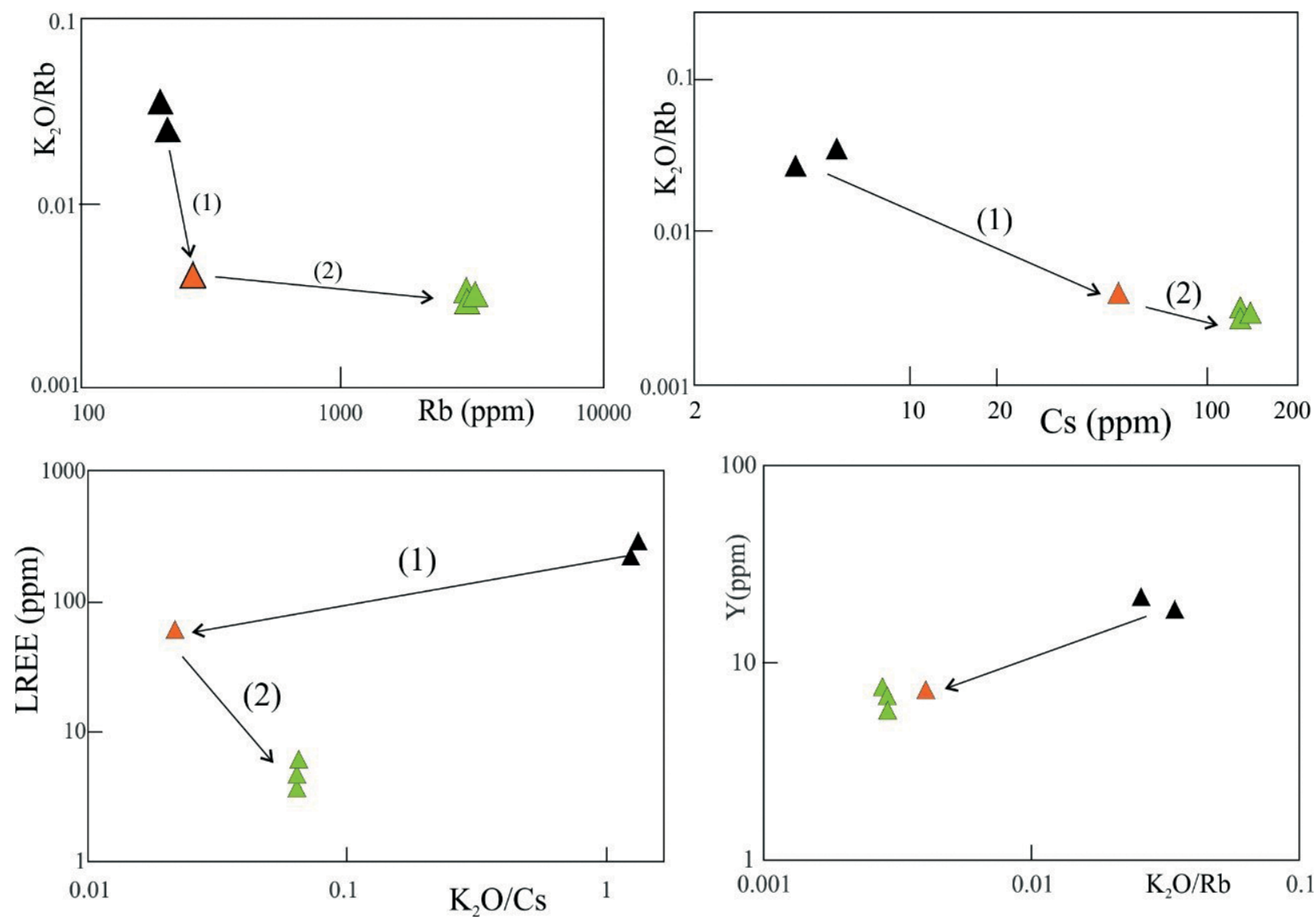

Figura 16. Selected variation diagrams (A) $\mathrm{K}_{2} \mathrm{O} / \mathrm{Rb}$ vs $\mathrm{Rb}$; (B) $\mathrm{K}_{2} \mathrm{O} / \mathrm{Rb}$ vs Cs; (C) LREE vs $\mathrm{K}_{2} \mathrm{O} / \mathrm{Cs}$; (D) $\mathrm{Y}$ vs $\mathrm{K}_{2} \mathrm{O} / \mathrm{Rb}$, showing the magma evolution of the Serra Branca granites and amazonite pegmatites for a fractional crystallization of (1) $\pm \mathrm{K}$-feldspars, titanite, apatite and allanite; (2) apatite, titanite and allanite. Legend: Serra Branca granite (black triangle), fine-grained leucogranite facies of the Serra Branca granites (orange triangle), and Serra Branca amazonite pegmatite (green triangle). 
(Snook 2014), were used to compare with the Serra Branca amazonite pegmatite. The pegmatites from the Hearn Province is divided into two groups: hybrid pegmatites and simple pegmatites. The hybrid pegmatites represent complex-type hybridized pegmatites, due to metasomatic interaction with the host rocks (McKeough et al. 2013).

The Serra Branca amazonite pegmatite shows REE patterns very distinct from both pegmatite groups of the Hearne Province and Evje-Iveland (Fig. 17). The REE pattern of the Serra Branca amazonite pegmatite are characterized by very low REE contents mainly LREE, with LREE/HREE ratios $>1$. On the other hand, the REE patterns of pegmatites from the Hearne Province and Evje-Iveland show deep negative $\mathrm{Eu}$ anomalies, and most of them have LREE/HREE ratios $\sim 1$,

The Serra Branca amazonite pegmatite spidergrams (Fig. 18) normalized to the Sun (1980) chondrite values are distinct from both the Evje-Iveland and those of the Hearne Province pegmatites by lower Th, U, LREE, $\mathrm{P}$ and higher $\mathrm{Cs}, \mathrm{Rb}, \mathrm{Pb}$ contents. Besides that, the Serra Branca amazonite pegmatite is geochemically distinct from the Evje-Iveland pegmatite by peak at $\mathrm{Sr}$, lower $\mathrm{Ti}$, and higher $\mathrm{Ba}, \mathrm{K}, \mathrm{Nb}$ and $\mathrm{Ta}$ contents (Fig. 18). The pegmatites from Evje-Iveland share similar incompatible elements patterns, except by lower contents of $\mathrm{Ba}$ and $\mathrm{Sr}$ recorded in the amazonite mineralized pegmatite.

The simple pegmatites of the Hearne Province show a geochemical uniform behavior, and lower $\mathrm{Ta}$ and $\mathrm{Nb}$ and higher $\mathrm{Ti}$ contents compared to the Serra Branca amazonite pegmatite.
The hybrid Hearne Province pegmatites show distinct incompatible element patterns. Compared to the Serra Branca amazonite pegmatite, the Hearne Province pegmatites show higher and lower $\mathrm{Ti}, \mathrm{Sr}, \mathrm{Nb}, \mathrm{Ta}$ and $\mathrm{Ba}$ contents, but are always $\mathrm{U}-$, and Th-rich and $\mathrm{Cs}, \mathrm{Pb}, \mathrm{Rb}$ and $\mathrm{Ba}$ depleted. It suggests that metasomatic interaction with the host rocks was not a process involved in the Serra Branca amazonite pegmatite magma evolution.

\section{CONCLUSIONS}

The Serra Negra and Serra Branca granitoids resulted from distinct degree of partial melting of similar sources, and have crystallization ages $594 \pm 4 \mathrm{Ma}$ and $563 \pm 2 \mathrm{Ma}$, respectively. The Serra Negra granites were emplaced syn- to tardi- transcurrent events, associated to the Lastro and Vieirópolis shear zones, and crystallized in the middle crustal levels under higher $\mathrm{fO}_{2}$ conditions and temperatures within the $711-751^{\circ} \mathrm{C}$ interval.

The Serra Branca granites are post-transcurrent (post-orogenic), emplaced at shallower levels, under high $\mathrm{fO}_{2}$. The Serra Branca granitic magma evolved by fractional crystallization of \pm K-feldspar, titanite, allanite, apatite leading to melts rich in incompatible elements, the Serra Branca leucogranitic facies, and the Serra Branca amazonite pegmatite.

The Serra Branca amazonite pegmatite is the first pegmatite characterized mineralogically and geochemically as a NYF-type gadolinite subtype within the BP and comprise rare pegmatites with economic importance outside the Seridó

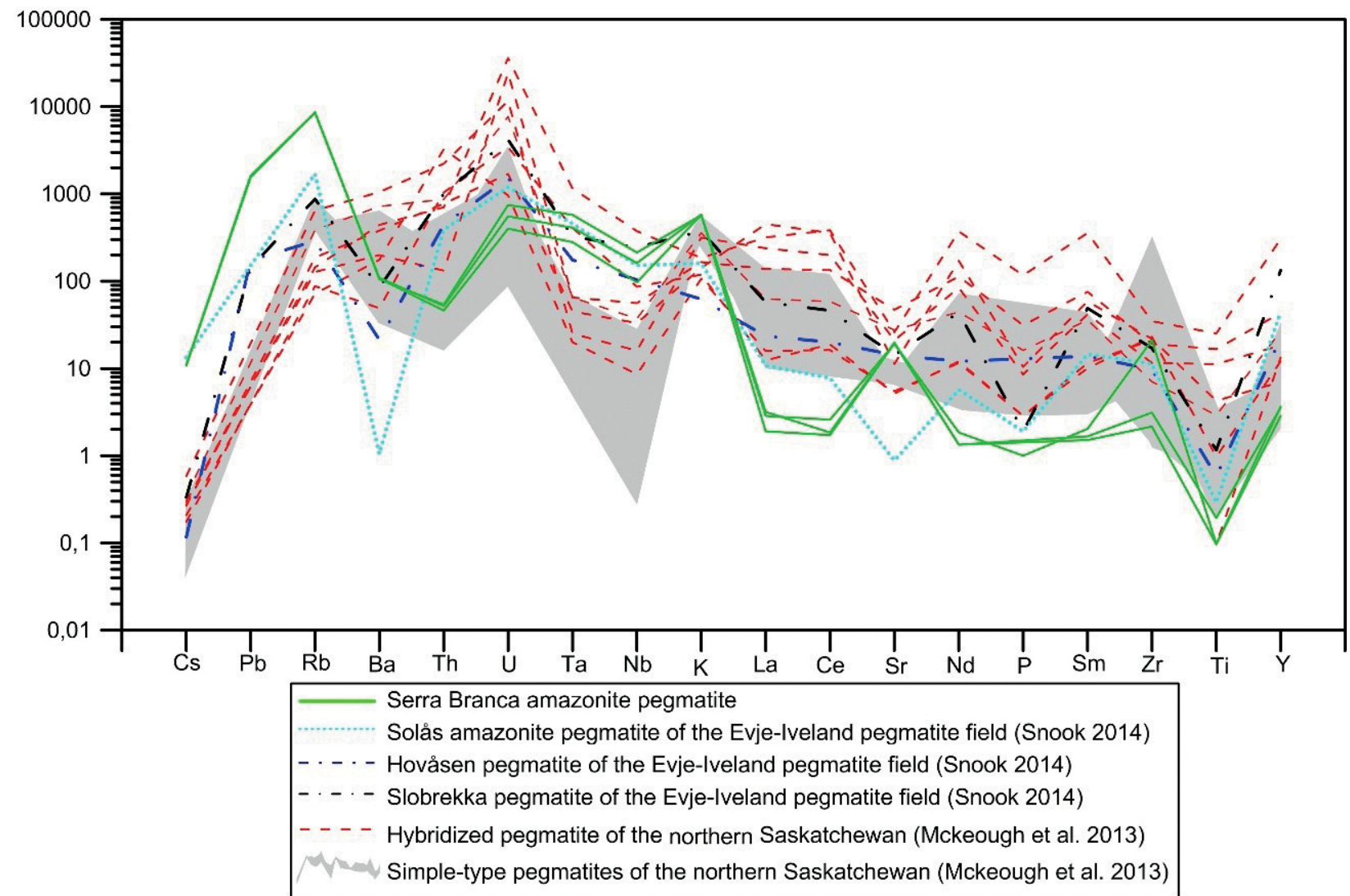

Figure 17. Comparison of spidergrams for the Serra Branca amazonite pegmatite, pegmatites of the Evje-Iveland pegmatite field (Snook 2013) and the simple and hybrid pegmatites from the Nothern Saskatchewan (McKeough et al. 2013) normalized to the chondrite values of Sun (1980). 


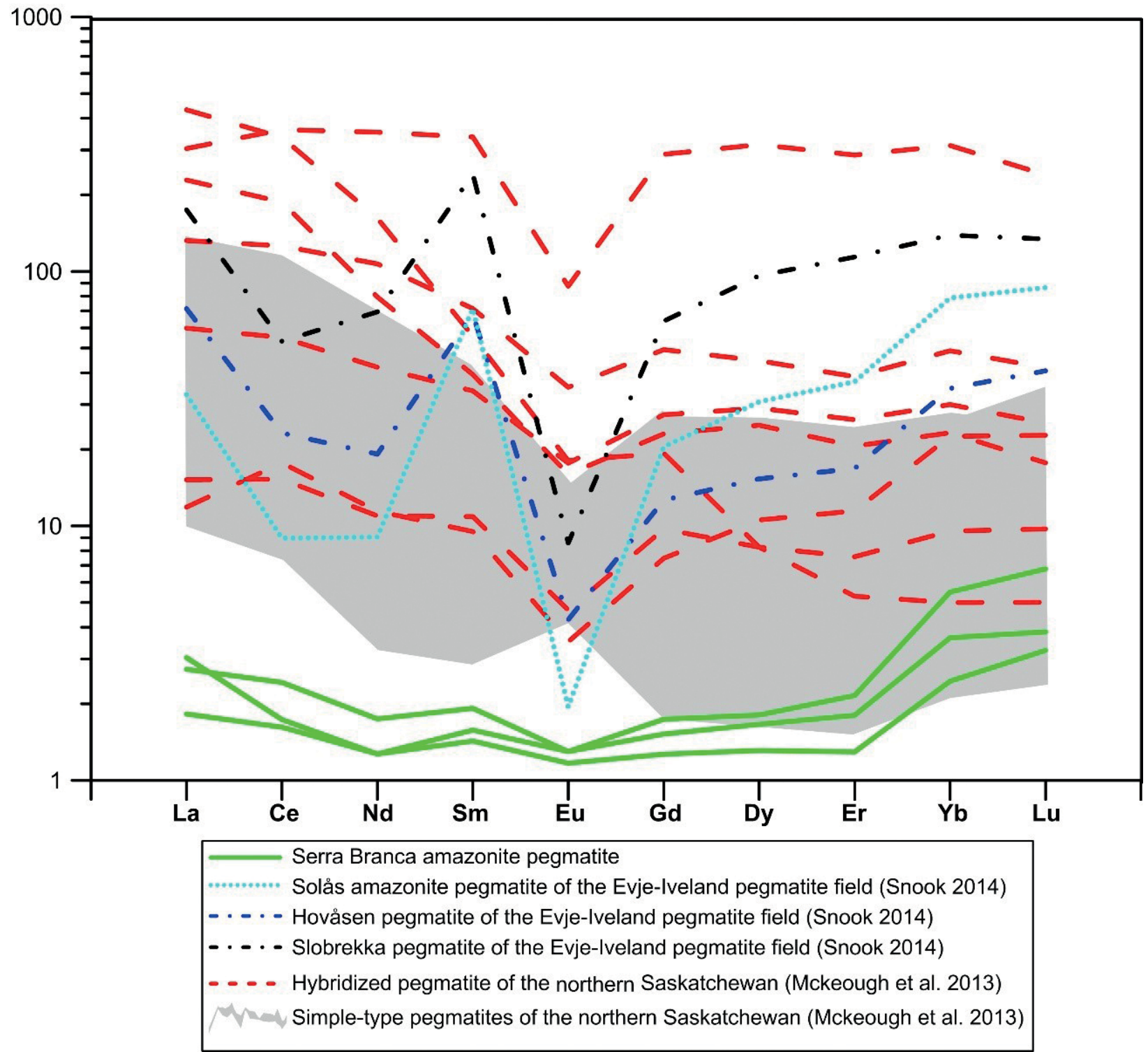

Figure 18. Rare earth elements (REE) pattern from the Serra Branca amazonite pegmatite, pegmatites of the Evje-Iveland pegmatite field (Snook 2013) and the simple and hybrid pegmatites from the Northern Saskatchewan (McKeough et al. 2013) normalized to the chondrite values of Nakamura (1974). Symbols as in Figure 15.

Pegmatite Province. They constitute, worldwide, a geochemically unique pegmatite occurrence of NYF type, due their low LREE, high $\mathrm{Pb}$ and $\mathrm{Rb}$ contents.

\section{ACKNOWLEDGMENTS}

We are grateful to the GRANISTONE S/A company for providing support to our research and for the supply of pegmatite samples. We also thank the Coordenação de Aperfeiçoamento de Pessoal de Nível Superior (CAPES) for scholarships granted to Igor Manoel Belo de Albuquerque e Souza, Glenda Lira Santos and José Ferreira de Araújo Neto. We would like to express our gratitude to Dr. Axel Müller for his general assistance with this research. We also thank Professor Dr. Nilson Botelho (Universidade de Brasília, Brazil) for the electron microprobe analysis.

\section{ARTICLE INFORMATION}

Manuscript ID: 20190083. Received on: 08/31/2019. Approved on: 02/21/2020.

I.M.B.A.S. wrote the first manuscript draft, worked on sample preparation, analysis and interpretation, drew most of the figures and prepared all tables; I.P.G. worked on the interpretation of the geochronological data, whole-rock and mineral chemistry data, gave support in all chapters of the manuscript, and drew some figures (12 and 13); S.B.B. participated in the field work, sample collecting, provided support and advisement regarding whole-rock and pegmatite descriptions and interpretations; G.L.S. participated of the field work, sample preparation, chemical and mineralogical interpretation of the pegmatite, and contributed to text reviewing; J.F.A.N. helped with field geology, petrographic descriptions and text reviewing.

Competing interests: The authors declare no competing interests. 


\section{REFERENCES}

Abbot R.N. 1985. Muscovite-bearing granites in the AFM liquidus projection. Canadian Mineralogist, 23:553-561.

Abbott R.N., Clarke D.B. 1979. Hypothetical liquidus relationships in the system $\mathrm{Al}_{2} \mathrm{O}_{3}-\mathrm{FeO}-\mathrm{MgO}$ projected from quartz, alkali feldspar and plagioclase, $\mathrm{a}(\mathrm{H} 2 \mathrm{O})<1$. Canadian Mineralogist, 17:549-560.

Ague J.J. 1997. Thermodynamic calculation of emplacement pressures for batholithic rocks, California: Implication for the aluminumin-hornblende barometer. Geology, 25(6):563-566. https://doi. org/10.1130/0091-7613(1997)025\%3C0563:TCOEPF\%3E2.3.CO;2

Ague J.J., Brandon M.T. 1992. Tilt and northward offset of Cordilleran batholiths resolved using igneous barometry. Nature, 360:146-149. https:// doi.org/10.1038/360146a0

Albarède F., Telouk P., Blichert-Toft J., Boyet M., Agranier A., Nelson B. 2004. Precise and accurate isotopic measurements using multiple-collector ICPMS. Geochimica et Cosmochimica Acta, 68(12):2725-2744. https:// dx.doi.org/10.1016/j.gca.2003.11.024

Almeida F.F.M., Hasui Y., Brito Neves B.B., Fuck R. 1981. Brazilian structural provinces: an introduction. Earth Science Reviews, 17(1-2):1-29. https://doi.org/10.1016/0012-8252(81)90003-9

Anderson J.L., Smith D.R. 1995. The effects of temperature and $\mathrm{fO}_{2}$ on the Al-in-hornblende barometer. American Mineralogist, 80(5-6):549-559. https://doi.org/10.2138/am-1995-5-614

Araújo Neto J.F., Lira Santos G., Souza I.M.B.A., Barreto S.B., Santos L.C.M.L., Bezerra J.P.S., Carrino T.A. 2018. Integration of remote sensing, airborne geophysics and structural analysis to geological mapping: a case study of the Vieirópolis region, Borborema Province, NE Brazil. Geologia USP. Série Científica, 18(3):89-103. https://doi.org/10.11606/issn.2316-9095.v18-140834

Archanjo C.J., Fetter A. 2004. Emplacement setting of the granite sheeted pluton of Esperança (Brasiliano orogen, Northeastern Brazil). Precambrian Research, 135(3):193-215. http://dx.doi.org/10.1016/j. precamres.2004.08.008

Archanjo C.J., Hollanda M.H.B.M., Rodrigues S.W.O., Brito Neves B.B.B, Armstrong R. 2008. Fabrics of pre- and syntectonic granite plutons and chronology of shear zones in the Eastern Borborema Province, NE Brazil. Journal of Structural Geology, 30(3):310-326. http://dx.doi.org/10.1016/j. jsg.2007.11.011

Barreto S.B., Muller A., Araujo Neto J.F., Bezerra J.P.S., Souza I.M.B.A., França R.H.M., Santos L.C.M.L. 2016. Vieirópolis Pegmatite Field, Northwest of Paraíba State, Brazil: New Occurrences of Amazonite Pegmatites. In: Jacobson M.I. (ed.), Second Eugene E. Foord Pegmatite Symposium: Abstracts, Short Papers, Posters and Program. Denver, Friends of Mineralogy, Colorado Chapter, p. 24-26.

Beurlen H., Da Silva M.R.R., Thomas R., Soares D.R., Olivier P. 2008. $\mathrm{Nb}-\mathrm{Ta}$-(Ti-Sn)-oxide mineral chemistry as tracers of rare-element granitic pegmatite fractionation in the Borborema Province, Northeast Brazil. Mineralium Deposita, 43(2):207-228. http://dx.doi.org/10.1007/ s00126-007-0152-4

Beurlen H., Rhede D., Da Silva M.R.R., Thomas R., Guimaraes I.P. 2009. Petrography, Geochemistry and Chemical Electron Microprobe U-Pb-Th dating of Pegmatitic Granites in Borborema Province, Northeastern Brazil: a Possible Source of Rare Element Granitic Pegmatites. Terrae, 6(1):59-71.

Blundy J.D., Holland T.J.B. 1990. Calcic amphibole equilibria and a new amphibole plagioclase geothermometer. Contributions to Mineralogy and Petrology, 104:208-224. https://doi.org/10.1007/BF00306444

Botcharnikov R.E., Koepke J., Holtz F., McCammon C., Wike M. 2005. The effect of water activity on the oxidation and structural state of $\mathrm{Fe}$ in a ferro-basaltic melt. Geochimica et Cosmochimica Acta, 69(21):5071-5085. https://doi.org/10.1016/j.gca.2005.04.023

Brito Neves B.B., Santos E.J., Van Schmus W.R. 2000. Tectonic History of the Borborema Province. In: Cordani U.G., Milani E.J., Thomaz Filho A., Campos D.A. (eds.), Tectonic Evolution of South America. Rio de Janeiro, 31st. International Geological Congress, p. 151-182.

Buddington A.F., Lindsley D.H. 1964. Iron-titanium oxide minerals and synthetic equivalents. Petrology, 5(2):310-357. https://doi.org/10.1093/ petrology/5.2.310
Černý P. 1991a. Fertile granites of Precambrian rare-element pegmatite fields: is geochemistry controlled by tectonic setting or source lithologies? Precambrian Research, 51(1-4):429-468. https://doi. org/10.1016/0301-9268(91)90111-M

Černý P. 1991b. Rare-element granitic pegmatites. Part 1: Anatomy and internal evolution of pegmatite deposits. Part 2: Regional to global environments and petrogenesis. Geoscience Canada, 18(2):49-81.

Černý P., Ercit T.S. 2005. The classification of granitic pegmatites revisited. The Canadian Mineralogist, 43(6):2005-2026. https://doi.org/10.2113/ gscanmin.43.6.2005

Corfu F., Hanchar J.M., Hoskin P.W.O., Kinny P. 2003. Atlas of zircon textures. Reviews in Mineralogy and Geochemistry, 51(1):469-500. https:// doi.org/10.2113/0530469

Czamanske G.K., Wones D.R. 1973. Oxidation during magmatic differentiation, Finnmarks Complex, Oslo Area, Norway: Part 2, the mafic silicate. Journal of Petrology, 14(3):349-380. https://doi.org/10.1093/petrology/14.3.349

Da Silva M.R.R., Höll R., Beurlen H. 1995. Borborema Pegmatitic Province: geological and geochemical characteristics. Journal of South America Earth Sciences, 8(3-4):355-364. https://doi. org/10.1016/0895-9811(95)00019-C

Dantas E.L. 1997. Geocronologia U-Pb e Sm-Nd de terrenos arqueanos e paleoproterozoicos do Maciço Caldas Brandão, NE do Brasil. Thesis, Instituto de Geociências e Ciências Exatas, Universidade Estadual Paulista, Rio Claro, 208 p.

Deer W.A., Howie R.A., Zussman J. 1992. An Introduction to the Rock Forming Minerals. 2nd ed. London, Longman, 696p.

Ercit T.S. 2005. REE-enriched granitic pegmatites. In: Linnen R.L., Samson I.M. (eds.). Rare-Element Geochemistry and Mineral Deposits. Geological Association of Canada, Short Course Notes. 17:175-199.

Ernst W.G., Liu J. 1998. Experimental phase-equilibrium study of Aland Ti-contents of calcic amphibole in MORB - A semiquantitative thermobarometer. American Mineralogist, 83(9-10):952-969. https://doi. org/10.2138/am-1998-9-1004

Ferreira J.A.M., Albuquerque J.P.T. 1969. Sinopse da geologia da Folha Seridó Recife, SUDENE, DRN/DG, Série Geológica, 52 p. (Boletim 18).

Ferreira V.P., Sial A.N., Jardim de Sá E.F. 1998. Geochemical and isotopic signatures of Proterozoic granitoids in terrenes of the Borborema structural province, northeastern Brazil. Journal of South America Earth Sciences, 11(5):439-455. https://doi.org/10.1016/S0895-9811(98)00027-3

Finger F., Schiller D. 2012. Lead contents of S-type granites and their petrogenetic significance. Contributions to Mineralogy and Petrology, 164(5):747-755. https://doi.org/10.1007/s00410-012-0771-3

France L., Ildefonse B., Koepke J., Bech F. 2010. New method to estimate the oxidation state of basaltic series from microprobe analyses. Journal of Volcanology and Geothermal Research, 189(3-4):340-346. https://doi. org/10.1016/j.jvolgeores.2009.11.023

Frost B.R., Barnes C.G., Collins W.J., Arculus R.J., Ellis D.J., Frost C.D. 2001. A geochemical classification of granitic rocks. Journal of Petrology, 42(11):2033-2048. https://doi.org/10.1093/petrology/42.11.2033

Gill J.B. 1981. Orogenic Andesites and Plate Tectonics. Berlin, Heidelberg, New York: Springer-Verlag, $390 \mathrm{p}$.

Guimarães I.P., Brito M.F.L., Lages G.A., Silva Filho A.F., Santos L., Brasilino R.G. 2016. Tonian granitic magmatism of the Borborema Province, NE Brazil: A review. Journal of South American Earth Science, 68:97-112. https:// doi.org/10.1016/j.jsames.2015.10.009

Guimarães I.P., Da Silva Filho A.F. 1998. Nd- and Srisotopic and U-Pb geochronologic constraints for the evolution of the shoshonitic Brasiliano Bom Jardim and Toritama complexes: evidence for a Transamazonian enriched mantle under Borborema tectonic province, Brazil. International Geology Review, 40(6):500-527. https://doi.org/10.1080/00206819809465221

Guimarães I.P., Da Silva Filho A.F., de Araújo D.B., de Almeida C.N. Dantas E. 2009. Trans-alkaline magmatism in the Serrinha-Pedro Velho Complex, Borborema Province, NE Brazil and its correlations with the magmatism in eastern Nigeria. Gondwana Research, 15(1):98-110. https:// doi.org/10.1016/j.gr.2008.06.011 
Guimarães I.P., Silva Filho A.F., Almeida C.N., Van Schmus W.R., Araújo J.M.M., Melo S.C., Melo E.B. 2004. Brasiliano (Pan-African) granitic magmatism in the Pajeú -Paraíba belt, Northeast Brazil: an isotopic and geochronological approach. Precambrian Research, 135:23-53.

Hammarstrom J.M., Zen E. 1986. Aluminum in hornblende: an empirical igneous geobarometer. American Mineralogist, 71 (11-12):1297-1313.

Hofmeister A.M., Rossman G.R. 1985. A spectroscopic study of irradiation coloring of amazonite: structurally hydrous, Pb-bearing feldspar. American Mineralogist, 70(7-8):794-804.

Hollanda M.H.B.M., Archanjo C.J., Souza L.C., Dunyi L., Armstrong R. 2011. Longlived Paleoproterozoic granitic magmatism in the Seridó-Jaguaribe domain, Borborema Province-NE Brazil. J. Journal of South American Earth Sciences, 32(4):287-300. http://dx.doi.org/10.1016/j.jsames.2011.02.008

Hollanda M.H.B.M., Pimentel M.M., Jardim de Sá E.F. 2003. Paleoproterozoic subductionrelated metasomatic signatures in the lithospheric mantle beneath NE Brazil: inferences from trace element and $\mathrm{Sr}-\mathrm{Nd}-\mathrm{Pb}$ isotopic compositions of Neoproterozoic high-K igneous rocks. Journal of South American Earth Sciences, 15(8):885-900. https://dx.doi. org/10.1016/S0895-9811(03)00014-2

Hollister L.S., Grissom G.C., Peters E.K., Stowell H.H., Sisson V.B. 1987. Confirmation of the empirical correlation of Al-in-hornblende with pressure of solidification of calc-alkaline plutons. American Mineralogist, 72(3-4):231-239.

Ishihara S. 1998. Granitoid series and mineralization in the Circum-Pacific Phanerozoic granitic belts: Resource Geology, 48(4):219-224. https:// dx.doi.org/10.1111/j.1751-3928.1998.tb00019.x

Jackson S.E., Pearson N.J., Griffin W.L., Belousova E.A. 2004. The application of laser ablation-inductively coupled plasma-mass spectrometry to in situ U-Pb zircon geochronology. Chemical Geology, 211(1-2):47-69. https://doi.org/10.1016/j.chemgeo.2004.06.017

Jardim de Sá E.F. 1994. A Faixa Seridó (Província Borborema, NE do Brasil) e o seu significado geodinâmico na Cadeia Brasiliana/Pan-Africana. Thesis, Instituto de Geociências, Universidade de Brasília, Brasília, 804 p.

Jardim de Sá E.F., Legrand J.M., McReath I. 1981. “Estratigrafia” de rochas granitóides na região do Seridó (RN-PB) com base em critérios estruturais. Revista Brasileira de Geociências, 11(1):50-57.

Johnson M.C., Rutherford M.J. 1988. Experimental calibration of an Aluminum-in-hornblende geobarometer applicable to calc-alkaline rocks. EOS, 69:1511.

Johnson M.C., Rutherford M.J. 1989. Experimental calibration of the aluminum-in-hornblende geobarometer with application to Long Valley caldera (California) volcanic rocks. Geology, 17(9):837-841. https://doi. org/10.1130/0091-7613(1989)017\%3C0837:ECOTAI\%3E2.3.CO;2

Leake B.E., Woolley A.R., Arps C.E.S, Birch W.D., Gilbert M.C., Grice J.D., Hawthorne F.C., Kato A., Kisch H.J., Krivovichev V.G., Linthout K., Laird J., Mandarino J., Maresch W.V., Nickel E.H., Rock N.M.S., Schumacher J.C., Smith D.C., Stephenson N.C.N., Ungaretti L., Whittaker E.J.W., Youzhi G. 1997. Nomenclature of amphiboles: Report of the subcommittee on amphiboles of the International Mineralogical Association Commission on New Minerals and Mineral Names. Canadian Mineralogist, 35(1):219-246.

Leterrier J., Jardim de Sá E.F., Bertrand J.M., Pin C. 1994. Ages U-Pb sur zircon de granitoides "brasilianos" de la ceinture do Seridó (Province Borborema, NE Brésil). Comptes Rendus Mathematique Academie des Sciences, 318:1505-1511.

Loiselle M.C., Wones D.R. 1979. Characteristics of Anorogenic Granites. Geological Society of America, Abstracts with Programs, 11:468.

London D. 2008. Pegmatites. Canada, The Canadian Mineralogist Special Edition, 368 p.

Mader U.K., Berman R.G. 1992. Amphibole thermobarometry, a thermodynamic approach, Current Research - Part E. Geological Survey of Canada Paper, 92(1E):393-400. https://doi.org/10.4095/133594

Martin R. 2004. Where do LCT and NYF pegmatites fit in? A contribution to a revised classification of granitic pegmatites. Geological Society of American Denver Annual Meeting Abstracts with Programs, 36(5):44.

Martin R.F., De Vito C., Pezzotta F. 2008. Why is amazonite K-feldspar an earmark of NYF-type granitic pegmatites: clues from hybrid pegmatites in Madagascar. American Mineralogist, 93(2-3):263-269. https://doi. org/10.2138/am.2008.2595

McKeough M.A., Lentz D.R., McFarlane C.R.M., Brown J. 2013. Geology and evolution of pegmatite-hosted U-Th \pm REE-Y-Nb Mineralization, Kulyk, Eagle, and Karin Lakes region, Wollaston Domain, northern Saskatchewan, Canada: examples of the dual role of extreme fractionation and hybridization processes. Journal of Geosciences, 58:321-346. https://doi. org/10.3190/jgeosci.153

McMurry J., Long L.E., Sial A.N. 1987. Petrology and isotope systematics of magma mushes: some porphyritic granitoids of northeastern Brazil. Revista Brasileira de Geociências, 17(4):473-480.

Medeiros V.C., Amaral C.A., Rocha D.E.G.A. 2005. Programa de Geologia do Brasil - PGB. Folha SB.24-Z-A Sousa. Escala 1:250.000. Recife, CPRM.

Meunier A.R. 1964. Succession stratigraphique et passages lateraux dus au metamorphisme dans la Série Ceará, Antecambrien du Nord-Est brésilien. Comptes Rendus Mathematique Academie des Sciences, 259:3796-3799.

Nachit H., Razafimahefa N., Stussi J.M., Carron J.P. 1985. Composition chimique des biotites et typologie magmatique des granitoides. Comptes Rendus Mathematique Academie des Sciences, 301: 813-818.

Nakamura N. 1974. Determination of REE, $\mathrm{Ba}, \mathrm{Mg}, \mathrm{Na}$ and $\mathrm{K}$ in carbonaceous and ordinary chondrites. Geochimica et Cosmochimica Acta, 38(5):757-775. https://doi.org/10.1016/0016-7037(74)90149-5

Nascimento M.A.L., Antunes A.F., Galindo A.C., Jardim de Sá E.F., Souza Z.S. 2000. Geochemical signatures of the Brasiliano-age plutonism in the Seridó belt, Northeastern Borborema Province (NE Brazil). Revista Brasileira de Geociências, 30(1):161-164.

Nascimento M.A.L., Galindo A.C., Medeiros V.C. 2015. Ediacaran to Cambrian magmatic suites in the Rio Grande do Norte domain, extreme Northeastern Borborema Province (NE of Brazil): Current knowledge. Journal of South American Earth Sciences, 58:281-299. https://doi. org/10.1016/j.jsames.2014.09.008

Neves S.P., Bruguier O., Bosh D., Silva J.M.R., Mariano G. 2008. U-Pb ages of plutonic and metaplutonic rocks in southern Borborema Province (NE Brazil): timing of Brasiliano deformation and magmatism. Journal of South American Earth Sciences, 25:285-297. https://doi.org/10.1016/j. jsames.2007.06.003

Neves S.P., Bruguier O., Vauchez, A., Bosch D., Silva J.M.R., Mariano G. 2006. Timing of crust formation, deposition of supracrustal sequences, and Transamazonian and Brasiliano metamorphism in the East Pernambuco belt (Borborema Province, NE Brazil): Implications for western Gondwana assembly. Precambrian Research, 149(3-4):197-216. https://doi. org/10.1016/j.precamres.2006.06.005

Neves S.P., Mariano G. 1999. Assessing the tectonic significance of a large-scale transcurrent shear zone system: The Pernambuco lineament, northeastern Brazil. Journal of Structural Geology, 21(10):1369-1383. https://doi.org/10.1016/S0191-8141(99)00097-8

Neves S.P., Vauchez A., Feraud G. 2000. Tectono-thermal evolution, magma emplacement, and shear zone development in the Caruaru area (Borborema Province, NE Brazil). Precambrian Research, 99(1-2):1-32. https://doi. org/10.1016/S0301-9268(99)00026-1

Ostrooumov M., Banerjee A. 2005. Typomorphic features of amazonitic K-feldspar from the Keivy granitic pegmatite (Kola Peninsula, Russia). Schweizerische Mineralogische und Petrographische Mitteilungen, 85 (1):89-102.

Pearce J.A. 1996. A User's Guide to Basalt Discrimination Diagrams. In: Wyman D.A. (ed.), Trace Element Geochemistry of Volcanic Rocks: Applications for Massive Sulphide Exploration. Geological Association of Canada, Short Course Notes, v. 12, p. 79-113.

Pearce J.A., Bender J.F., De Long S.E., Kidd W.S.F., Low P.J., Güner Y., Saroglu F., Yilmaz Y., Moorbath S., Mitchell J.G. 1990. Genesis of collision volcanism in Eastern Anatolia, Turkey. Journal of Volcanology and Geothermal Research, 44(1-2):189-229.

Pearce J.A., Harris N.B.W, Tindle A.G. 1984. Trace element discrimination diagrams for the tectonic interpretation of granitic rocks. Journal of Petrology, 25(4):956-983. https://doi.org/10.1093/petrology/25.4.956

Rogers J.W. 1996. A History of Continents in the Past Three Billions Years. The Journal of Geology, 104(1):91-107. 
Rutter M.J., Van der Laan S.R., Wyllie P.J. 1989. Experimental data for a proposed empirical igneous geobarometer: Aluminium in hornblende at $10 \mathrm{kbar}$ pressure. Geology, 17(10):897-900. https://doi. org/10.1130/0091-7613(1989)017\%3C0897:EDFAPE\%3E2.3.CO;2

Sá J.M., Sousa L.C., Legrand J.M., Galindo A.C., Maia H.N., Fillippi R.R. 2014. U-Pb and Sm-Nd data of the Rhyacian and Statherian Orthogneisses from Rio Piranhas-Seridó and Jaguaribeano Terranes, Borborema Province, Northeast of Brazil. Revista do do Instituto de Geociências, Série Científica, 14(3):97-110. https://doi.org/10.5327/Z1519-874X201400030007

Santos E.J., Souza Neto J.A., Silva M.R.R., Beurlen H., Cavalcanti J.A.D., Silva M.G., Costa A.F., Santos L.C.M.L., Santos R.B. 2014. Metalogênese das porções norte e central da Província Borborema. In: Silva M.G., Neto M.B.R., Jost H., Kuyumijan R.M. (eds.), Metalogênese das Províncias Tectônicas Brasileiras. Brasil, CPRM, p. 343-388.

SchmidtM.W. 1992. Amphibole composition in tonalite as a function of pressure: An experimental calibration of the AI-in-hornblende barometer. Contributions to Mineralogy and Petrology, 110:304-310. https://doi.org/10.1007/BF00310745

Silva J.M.R., Mariano G. 2000. Geometry and kinematics of the Afogados da Ingazeira shear zone, northeast Brazil. International Geology Review, 42(1):86-95. https://doi.org/10.1080/00206810009465071

Silva Filho A.F., Guimarães I.P., Santos L., Armstrong R., Van Schmus W.R. 2016. Geochemistry, U-Pb geochronology, $\mathrm{Sm}-\mathrm{Nd}$ and O isotopes of ca. 50 Ma long Ediacaran High-K Syn-Collisional Magmatism in the Pernambuco Alagoas Domain, Borborema Province, NE Brazil. Journal of South American Earth Sciences, 68:134-154. https://doi.org/10.1016/j.jsames.2015.12.013

Snook B. 2014. Towards exploration tools for high purity quartz: An example from the South Norwegian EvjeIveland pegmatite belt. Thesis, Camborne School of Mines, University of Exeter.

Souza J.V. 1985. Geologia dos pegmatitos de metais raros da região $W$ e NW de Solonópole - CE. Fortaleza. Tese, Departamento de Geologia, Universidade Federal do Ceará, Fortaleza, 109 p

Souza Z.S., Martin H., Peucat J.J., Jardim de Sá E.F., Macedo M.H.F. 2007. Calc-alkaline magmatism at the archean-proterozoic transition: the Caicó Complex basement (NE Brasil). Jounal of Petrology, 48(11):2149-2185. https://doi.org/10.1093/petrology/egm055

Spear F.S. 1981. An experimental study of hornblende stability and compositional variability in amphibolite. American Journal of Science, 281:697-734. https://doi.org/10.2475/ajs.281.6.697

Sun S.S. 1980. Lead isotopic study of young volcanic rocks from mid-ocean ridges, oceanic islands and island arcs. Philophical Transactions of the Royal Society of London, A297(1431):409-445. https://doi.org/10.1098/rsta.1980.0224

Trindade R.I., Dantas E.L., Babinski M., Schmus W.R.V. 1999. Shortlived granitic magmatism along shear zone: evidence from $\mathrm{U}-\mathrm{Pb}$ zircon and sphene age of Caraúbas and Tourão granite. In: South American Symposium on Isotope Geology, 2, Argentina. Actas, p. 143-144.

Tulloch A.J., Challis G.A. 2000. Emplacement depths of PalezoicMesozoic plutons from western New Zealand estimated by hornblende-Al
geobarometry.NewZealand JournalofGeologyand Geophysics, 43(4):555-567. https://doi.org/10.1080/00288306.2000.9514908

Van Schmus W.R., Brito Neves B.B., Hackspacher P., Babinski M. 1995. $\mathrm{U} / \mathrm{Pb}$ and $\mathrm{Sm} / \mathrm{Nd}$ geochronolgic studies of eastern Borborema Province, northeastern Brazil: initial conclusions. Journal of South American Earth Sciences, 8(3-4):267-288.https://doi.org/10.1016/0895-9811(95)00013-6

Van Schmus W.R., Kozuch M., Brito Neves B.B. 2011. Precambrian history of the Zona Trasnversal of the Borborema Province, NE Brazil; Insights from $\mathrm{Sm}-\mathrm{Nd}$ and U-Pb geochronology. Journal of South American Earth Sciences, 31(2-3):227-25. https://dx.doi.org/10.1016/j.jsames.2011.02.010

Van Schmus W.R., Oliveira E.P., Silva Filho A.F., Toteu S.F., Penaye J., Guimarães I.P. 2008. Proterozoic links between the Borborema Province, NE Brazil, and the Central African Fold Belt. Geological Society of London, Special Publication, 294:69-99. https://doi.org/10.1144/SP294.5

Vauchez A., Egydio-Silva M. 1992. Termination of a continental scale strike-slip fault in partially melted crust: The West-Pemambuco shear zone, northeast Brazil. Geology, 20(11):1007-1010. https://doi. org/10.1130/0091-7613(1992)020\%3C1007:TOACSS\%3E2.3.CO;2

Vidal F.W.H., Nogueira Neto J.A. 2005. Minerais de Pegmatitos. In: Vidal F.W.H., Sales F.A.C.B., Roberto F.A.C., Sousa J.F., Mattos I.C. Rochas e Minerais Industriais do Estado do Ceará. Fortaleza, CETEM / UECE / DNPM / FUNCAP / SENAI, p. 67-82.

Watson E.B. 1979. Zircon saturation in felsic liquids: experimental results and applications to trace element geochemistry. Contributions to Mineralogy and Petrology, 70(4):407-419. https://doi.org/10.1007/BF00371047

Watson E.B., Harrison T.M. 1983. Zircon saturation revisited: temperature and composition effects in a variety of crustal magma types. Earth Planet Science Letters, 64(2):295-304. https://doi. org/10.1016/0012-821X(83)90211-X

Watson E.B., Harrison T.M. 1984. Accessory phases and the geochemica evolution of crustal magmas. Physics of the Earth and Planetary Interiors, 35(1-3):19-30. https://doi.org/10.1016/0031-9201(84)90031-1

Williams C.T. 1996. Analysis of rare earth minerals. In: Jones A., Wall F., Williams C.T. (eds.), Rare Earth Minerals: Chemistry Origin and Ore Deposits. London, Chapman and Hall, p. 193-226.

Williams I.S., Claesson S. 1987. Isotopic evidence for the Precambrian provenance and Caledonian metamorphism of high grade paragneisses from the Seven Nappes, Scandinavian Caledonides. Ion microprobe zircon U-Pb-Th. Contribution to Mineralogy and Petrology, 97(2):205-217. https:// doi.org/10.1007/BF00371240

Wise M.A. 1999. Characterization and classification of NYF-type pegmatites. Canadian Mineralogist, 37(Part 3):802-803.

Wise M.A. 2017. Mineralogy and mineral chemistry of NYF-type granitic pegmatites. NGF Abstracts and Proceedings, 2:177-180.

Wones D.R. 1989. Significance of the assemblage titanite + magnetite + quartz in granitic rocks. American Mineralogist, 74(7-8):744-749. 